Van Damme A., Degryse F., Smolders E., Sarret G., Dewit J., Swennen R. \& Manceau A. (2010)

Zinc speciation in mining and smelter contaminated overbank sediments by EXAFS

spectroscopy. Geochimica et Cosmochimica Acta 74: 3707-3720.

Author manuscript

The definitive version is available through www.sciencedirect.com

doi:10.1016/j.gca.2010.03.032

\title{
ZINC SPECIATION IN MINING AND SMELTER CONTAMINATED OVERBANK SEDIMENTS BY EXAFS SPECTROSCOPY
}

\author{
An Van Damme, ${ }^{a, *}$, Fien Degryse ${ }^{\mathrm{b}}$, Erik Smolders ${ }^{\mathrm{b}}$, Géraldine Sarret ${ }^{\mathrm{c}}$, Julie Dewit ${ }^{\mathrm{a}}$, \\ Rudy Swennen ${ }^{\mathrm{a}}$, Alain Manceau ${ }^{\mathrm{d}}$ \\ ${ }^{a}$ Geology Section, Department of Earth and Environmental Sciences, K.U.Leuven, \\ Celestijnenlaan 200E, 3001 Heverlee, Belgium \\ ${ }^{b}$ Division Soil and Water Management, Department of Earth and Environmental \\ Sciences, K.U.Leuven, Kasteelpark Arenberg 20, 3001 Heverlee, Belgium \\ ${ }^{c}$ Environmental Geochemistry Group, LGIT, University Joseph Fourier and CNRS, \\ 38041 Grenoble Cedex 9, France \\ ${ }^{d}$ Mineralogy \& Environments, LGCA, University Joseph Fourier and CNRS, 38041 \\ Grenoble Cedex 9, France \\ *Corresponding author: An.VanDamme@ees.kuleuven.be
}




\begin{abstract}
Overbank sediments contaminated with metalliferous minerals are a source of toxic metals that pose risks to living organisms. The overbank sediments from the Geul river in Belgium contain 4000 to $69000 \mathrm{mg} / \mathrm{kg} \mathrm{Zn}$ as a result of mining and smelting activities, principally during the 19 th century. Three main $\mathrm{Zn}$ species were identified by powder $\mathrm{Zn}$ K-edge EXAFS spectroscopy: smithsonite $\left(\mathrm{ZnCO}_{3}\right)$, tetrahedrally coordinated sorbed $\mathrm{Zn}$ (sorbed ${ }^{\mathrm{IV}} \mathrm{Zn}$ ), and $\mathrm{Zn}$-containing trioctahedral phyllosilicate. Smithsonite is a primary mineral, which accounts for approximately 20 to $60 \%$ of the $\mathrm{Zn}$ in sediments affected by mining and smelting of oxidized $\mathrm{Zn}$ ores (mostly carbonates and silicates). This species is almost absent in sediments affected by mining and smelting of both sulphidic $(\mathrm{ZnS}, \mathrm{PbS})$ and oxidized ores, presumably because of acidic dissolution associated with the oxidation of sulphides, as suggested by the lower $\mathrm{pH}$ of this second type of sediment $\left(\mathrm{pH}\left(\mathrm{CaCl}_{2}\right)\right.$ $<7.0$ vs. $\mathrm{pH}\left(\mathrm{CaCl}_{2}\right)>7.0$ for the first type). Thus, sulphide minerals in sediment deposits can act as a secondary source of dissolved metals by a chemical process analogous to acid-mine drainage. The sorbed ${ }^{\mathrm{IV}} \mathrm{Zn}$ component ranges up to approximately $30 \%$, with the highest proportion occurring at $\mathrm{pH}\left(\mathrm{CaCl}_{2}\right)<7.0$ as a result of the readsorption of dissolved $\mathrm{Zn}^{2+}$ on sediments constituents. Kerolite-like Zn-rich phyllosilicate is the major secondary species in all samples, and in some the only detected species, thus providing the first evidence for pervasive sequestration of $\mathrm{Zn}$ into this newly formed precipitate at the field scale.
\end{abstract}




\section{INTRODUCTION}

Historical mining and smelting of metal ores often heavily affected the local environment in the neighbourhood of extraction and production sites. In the area of the Geul river (E-Belgium and S-Netherlands), approximately 1.1 million tons of zinc and 0.13 million tons of lead were produced during the 19th century and the beginning of the 20th century (Dejonghe et al., 1993, 1998), resulting in elevated concentrations of $\mathrm{Zn}, \mathrm{Pb}$ and Cd in the nearby overbank and river sediments (Leenaers, 1989; Swennen et al., 1994; Stam, 2002). Because overbank sediments are deposited nearly horizontally on floodplain surfaces, analysis of sediment layers provides a historical record of the river contamination (Ottesen et al., 1989; Miller and Orbock Miller, 2007).

Zinc contamination may present risks for living organisms. Since the bioavailability, mobility and toxicity of metal contaminants strongly depend on their chemical forms, a detailed knowledge of their speciation is required to evaluate their impact on ecosystems. The weathering of primary $\mathrm{Zn}$-minerals releases aqueous $\mathrm{Zn}^{2+}$, which can be sorbed on soil constituents, such as organic matter, Fe- and Mn-(oxyhydr)oxides and clay minerals, or precipitated with other solute species, such as $\mathrm{Si}$ to form a $\mathrm{Zn}$-rich phyllosilicate, $\mathrm{Al}$ to form a layered double hydroxide ( $\mathrm{Zn}-\mathrm{LDH})$, or even carbonates to form hydrozincite. The nature of these primary and secondary $\mathrm{Zn}$-containing phases has been studied extensively by powder Zn K-edge EXAFS (extended X-ray absorption fine structure) spectroscopy (Manceau et al., 2002; D'Amore et al., 2005) in soils and sediments contaminated by mining and smelting operations, weathering of galvanization products, and application on land of dredged sediments and sewage sludges (Manceau et al., 2000; Isaure et al., 2002, 2005; Roberts et al., 2002; Scheinost et al., 2002; Sarret et al., 2004; Panfili et al., 2005; Nachtegaal et al., 2005; Kirpichtchikova et al., 2006; Schuwirth et al., 2007; Jacquat et al., 2008, 2009). These studies provided insight into how the nature of the secondary $\mathrm{Zn}$ species is influenced by the local chemical conditions, including soil $\mathrm{pH}, \mathrm{Zn}$ concentration relative to the type and amount of sorption sites, $\mathrm{Si}$ and $\mathrm{Al}$ concentrations, and $\mathrm{CO}_{2}$ partial pressure. 
This work further documents the distribution of $\mathrm{Zn}$ between primary minerals, sorbed species and newly formed precipitates at the field scale. Two representative vertical profiles in the overbank sediments of the Geul river were studied to obtain information on the temporal evolution ( $<200$ years) of mineral weathering and transformation reactions. Historical relationships between sediment deposition, contamination source and speciation are discussed to advance understanding of the geochemistry of $\mathrm{Zn}$ in this environmental system.

\section{MATERIALS AND METHODS}

\subsection{Site description and sampling}

Overbank and river sediment samples were collected from the catchment of the Geul river. The two most important mines along the Geul river were Plombières (named Bleiberg in German) and La Calamine (named Kelmis in German) (Fig. 1). Pre-industrial mining already occurred during the Middle Ages. Mining and smelting activities reached their apogee in the middle of the 19th century, and ceased in 1884. The smelters were located nearby the mines. Smelting of imported ores and mining at other locations continued in the first decades of the 20th century. Even today, metals are still introduced into the river system through the weathering and erosion of waste dumps (Kucha et al., 1996) and remobilization of contaminated overbank sediments. The ore minerals are composed predominantly of galena $(\mathrm{PbS})$ and sphalerite $(\mathrm{ZnS})$ at Plombières and several other smaller mines, and of a mixture of oxidized minerals, including smithsonite $\left(\mathrm{ZnCO}_{3}\right)$, hemimorphite $\left(\mathrm{Zn}_{4} \mathrm{Si}_{2} \mathrm{O}_{7}(\mathrm{OH})_{2} \cdot \mathrm{H}_{2} \mathrm{O}\right)$ and willemite $\left(\mathrm{Zn}_{2} \mathrm{SiO}_{4}\right)$ at La Calamine.

The samples were taken in the Belgian part of the catchment (Fig. 1), where the Geul river is incised in Palaeozoic sandstone, dolomite, limestone and shale (Swennen and Viaene, 1990). Vertical profiles were sampled on two locations in the overbank sediments. The cut banks, more than $2 \mathrm{~m}$ high, were sampled over 1-20 cm depth intervals within discrete sedimentary units. The first profile (LC samples) is situated $\sim 1$ $\mathrm{km}$ downstream of the former mine of La Calamine and upstream of Plombières, and thus received dominantly oxidized $\mathrm{Zn}$ minerals from La Calamine. The second sampling site (PB samples) is located downstream of the two mines, $\sim 7 \mathrm{~km}$ from La Calamine and $\sim 2$ 
$\mathrm{km}$ from Plombières, and received both oxidized and $\mathrm{Pb}-\mathrm{Zn}$ sulphide minerals from the mines in the area. In addition, a sample of river sediment (i.e. today's bedload) was collected near the border between Belgium and the Netherlands, $\sim 4 \mathrm{~km}$ downstream of the ancient mining centre of Plombières.

\subsection{Analytical methods}

All samples were dried at $30^{\circ} \mathrm{C}$ and passed through a $2 \mathrm{~mm}$ sieve. Total element concentrations were determined by atomic absorption spectroscopy (AAS) for $\mathrm{Zn}, \mathrm{Pb}$, $\mathrm{Mn}, \mathrm{Fe}, \mathrm{Ca}, \mathrm{Mg}, \mathrm{K}$ and $\mathrm{Al}$, and by inductively coupled plasma mass spectrometry (ICP$\mathrm{MS}$ ) for $\mathrm{Cd}$, As and $\mathrm{Cu}$, after hot acid digestion $\left(\mathrm{HCl} / \mathrm{HNO}_{3} / \mathrm{HF}\right)$. Total $\mathrm{S}$ was measured with a Ströhlein Sulfur Analyser. Organic carbon was analysed by the Walkley and Black method (Nelson and Sommers, 1982). The $\mathrm{pH}$, referred to as $\mathrm{pH}$ (water), was measured in a sediment/water suspension of $1 / 2.5 \mathrm{~kg} / \mathrm{L}$. Grain size was determined by laser diffraction after physical (disaggregation) and chemical (decalcification, removal of Fe and organic matter) pretreatment (Horckmans et al., 2007). Mineralogical analyses were performed by $\mathrm{X}$-ray diffraction (XRD, using $\mathrm{CuK} \alpha$ radiation) on bulk samples and/or concentrates, separated by sieving $(125-250 \mu \mathrm{m})$, density $(d>2.9 \mathrm{~g} / \mathrm{mL})$ and magnetic fractionation (Van Herreweghe et al., 2002).

Single extractions with $0.01 \mathrm{M} \mathrm{CaCl}_{2}$ (sediment to solution ratio of $1 / 10 \mathrm{~kg} / \mathrm{L}$ ) were performed following the procedure of the EC Standards, Measurements and Testing Programme (Quevauviller, 1998). Zinc concentrations and $\mathrm{pH}$, referred to as $\mathrm{pH}\left(\mathrm{CaCl}_{2}\right)$, were measured in the solutions. The $\mathrm{pH}\left(\mathrm{CaCl}_{2}\right)$ was lower than the $\mathrm{pH}$ (water) by 0.6 unit on average. The $\mathrm{CaCl}_{2}$ extract mimics the soil solution with respect to $\mathrm{pH}$ and ionic strength, and is therefore often used to predict the solid-liquid distribution of metals in soils (Houba et al., 1996; Degryse et al., 2003). The aqueous Zn concentrations in equilibrium with smithsonite $\left(\mathrm{ZnCO}_{3}\right)$ and with $\mathrm{Zn}$-kerolite $\left(\mathrm{Si}_{4} \mathrm{Zn}_{3} \mathrm{O}_{10}(\mathrm{OH})_{2} \cdot \mathrm{nH}_{2} \mathrm{O}\right)$ in a $0.01 \mathrm{M} \mathrm{CaCl}_{2}$ solution were calculated using MINTEQA2 v. 4.0 (Allison et al., 1991) for a $\mathrm{CO}_{2}$ partial pressure of $10^{-3}$ atm and a Si concentration of $10^{-4} \mathrm{M}$. Since the accuracy of the solubility product of Zn-kerolite is relatively low ( $\log K=8 \pm 6$; Manceau et al., 2000; Panfili et al., 2005), the saturation concentration of $\mathrm{Zn}$ in equilibrium with $\mathrm{Zn}$-kerolite was calculated for $\log K=8$ and 12 . 


\subsection{Powder Zn K-edge EXAFS spectroscopy}

Powder Zn K-edge X-ray absorption spectra were measured at room temperature on beamline BM26A (DUBBLE ; Nikitenko et al., 2008) at the European Synchrotron Radiation Facility (ESRF, Grenoble, France). The beam energy was calibrated with a Zn foil before the start of the measurements. Data were collected from pressed pellets in transmission mode using ionization chambers for concentrated samples ([Zn] $>10000$ $\mathrm{mg} / \mathrm{kg}$ ) and in fluorescence mode using a 9-element Ge-detector for diluted samples ([Zn] $<10000 \mathrm{mg} / \mathrm{kg}$ ). The pellets were oriented at $45^{\circ}$ from the incident X-ray beam, thus at an angle close enough to the $35^{\circ}$ "magic angle" to cancel any possible effects from preferential orientation (Manceau et al., 1990). Multiple scans were averaged to increase signal-to-noise ratios. Spectra were acquired on 0-2 $\mathrm{mm}$ bulk fractions, on 1-2 $\mathrm{mm}$ and $125-250 \mu \mathrm{m}$ size fractions separated from the $0-2 \mathrm{~mm}$ fraction by dry sieving, and on the $0-2 \mu \mathrm{m}$ size fraction separated from the $0-2 \mathrm{~mm}$ fraction by centrifugation.

EXAFS spectra were extracted from X-ray absorption spectra by normalizing the signal amplitude to the jump in absorbance at the K-edge and by simulating the post-edge total absorption with a spline function. The kinetic energy $\left(E_{k}\right)$ of the photoelectron was converted to wave vector $(k)$ values by taking the energy origin $\left(E_{k}=0\right)$ at the half-height of the absorption jump. Data were reduced using the software code Athena (Newville, 2001; Ravel and Newville, 2005). The number of components (i.e. Zn species) necessary to reproduce the complete set of $k^{3}$-weighted EXAFS spectra was determined by principal component analysis (PCA; Wasserman et al., 1999; Ressler et al., 2000; Manceau et al., 2002). The number of meaningful components was evaluated with five criteria: the indicator parameter IND, the total normalized sum-square residual $\left(\mathrm{NSS}_{\text {tot }}\right)$ defined as the sum of the squares of the residuals normalized to the sum of the squares of the data values over all points in the dataset, the marginal decrease of $\mathrm{NSS}_{\text {tot }}$ upon addition of a new component, and visual inspections of the components and spectral reconstructions (Malinowski, 1977, 1978; Manceau and Matynia, 2010). Then, Zn species were identified by target transformation, a procedure to evaluate whether a reference spectrum is a likely component of the dataset. Two criteria were used for this assessment: the NSS of the reconstruction to the original reference spectrum, and the visual comparison of the two 
spectra. Finally, the fractional amounts of the total $\mathrm{Zn}$ among all forms in the samples were determined by linear combination fitting (LCF) of the experimental EXAFS spectra with the reference spectra positively identified by target transformation. An additional species was added to the LCF reconstruction if the NSS decreased by at least $10 \%$. PCA and LCF were performed using the approach and softwares developed by A. Manceau and M.A. Marcus on beamline 10.3.2 of the Advanced Light Source (ALS, Berkeley, US; Manceau et al., 1996, 2002; Marcus et al., 2004). All spectra were analysed over the 2.5$10.5 \AA^{-1} k$-interval.

A database of Zn minerals, Zn-substituted and Zn-sorbed references, and Zn organic compounds was used to identify $\mathrm{Zn}$ species. The database contained smithsonite (from a natural sample), willemite, hemimorphite, franklinite, gahnite (Scheinost et al., 2002), sphalerite (Schuwirth et al., 2007), zincite (Voegelin et al., 2005), hydrozincite (Jacquat et al., 2008), a series of $\mathrm{Zn}$-containing kerolites $\left(\mathrm{Si}_{4}\left(\mathrm{Zn}_{x} \mathrm{Mg}_{3-x}\right) \mathrm{O}_{10}(\mathrm{OH})_{2} \cdot \mathrm{nH}_{2} \mathrm{O}\right)$ with $x=0.03$, 1.35 or 3.00 (Manceau et al., 2000; Schlegel et al., 2001a) or $x=2.40$ (Voegelin et al., 2005), trioctahedral Zn-phyllosilicate precipitated at the layer edges of montmorillonite, Zn-sorbed montmorillonite (Schlegel and Manceau, 2006), natural Znsubstituted Redhill montmorillonite (Manceau et al., 2005), Zn layered double hydroxide ( $\mathrm{Zn}-\mathrm{LDH}, \mathrm{Zn}_{2} \mathrm{Al}(\mathrm{OH})_{6} \mathrm{Cl}$; Voegelin et al., 2005), Zn-substituted goethite (Manceau et al., 2000), Zn-sorbed ferrihydrite, Zn-reacted gibbsite (Roberts et al., 2002), Zn-reacted hydroxylapatite at pH 5 and pH 6 and at various metal concentrations (Panfili et al., 2005), Zn parahopeite, $\mathrm{Zn}$ acetate, $\mathrm{Zn}$ citrate, $\mathrm{Zn}$ malate, $\mathrm{Zn}$ oxalate, $\mathrm{Zn}$ phytate, $\mathrm{Zn}$ sorbed on humic and fulvic acids at various concentrations, and aqueous $\mathrm{Zn}\left(\mathrm{ZnNO}_{3}\right.$ solution at pH 4) (Sarret et al., 2002, 2004). 


\section{RESULTS}

\subsection{Chemical and mineralogical composition}

Characteristics of the samples are reported in Table 1. The samples have a $\mathrm{pH}$ (water) between 6.7 and 8.0 and an organic carbon content between 0.4 and $4.4 \%$. The $\mathrm{Zn}$ concentration ranges from $3200 \mathrm{mg} / \mathrm{kg}$ to $69000 \mathrm{mg} / \mathrm{kg}$. Contamination undoubtedly results from the past mining and smelting activities because the overbank sediments at $5 \mathrm{~km}$ upstream of La Calamine contain less than $400 \mathrm{mg} / \mathrm{kg}$ (data not shown). The LC profile is the most contaminated in zinc, with $\mathrm{Zn}$ concentrations above $10000 \mathrm{mg} / \mathrm{kg}$. The Zn pattern shows two maxima, $69000 \mathrm{mg} / \mathrm{kg}$ at $168-183 \mathrm{~cm}$ depth (LC04) and $47000 \mathrm{mg} / \mathrm{kg}$ at $93-108 \mathrm{~cm}$ depth (LC09) (not shown). The highest concentrations of $\mathrm{Pb}(5400 \mathrm{mg} / \mathrm{kg}), \mathrm{Cd}(29 \mathrm{mg} / \mathrm{kg}), \mathrm{As}(89 \mathrm{mg} / \mathrm{kg})$ and $\mathrm{Cu}(73 \mathrm{mg} / \mathrm{kg})$ are reached in the upper part of the PB profile $(<59 \mathrm{~cm})$, consistent with the mining and smelting of $\mathrm{Pb}-\mathrm{Zn}$ sulphides in Plombières (Swennen et al., 1994). The bulk sediments contain mainly quartz, as determined by XRD, and also some dolomite and aluminosilicates (microcline, albite). Zinc-minerals identified by XRD in the overbank sediments and the present-day river sediment are smithsonite, hemimorphite and willemite (Table 1). Sphalerite was detected only in the river sediment. No Pb-bearing phase was detected by XRD.

\subsection{Identification of $\mathrm{Zn}$ species}

The whole set of powder Zn K-edge EXAFS spectra is shown in Fig. 2. The spectra were classified in two groups based on their shape, and thus nature of the main $\mathrm{Zn}$ species. The first group comprises only spectra from bulk LC samples. The bulk PB samples and their grain size fractions, the clay fraction from LC at 168-183 cm depth (LC04) and the river sediment (GE10) are all classified in the second group. The two populations mostly differ in the shape of the third oscillation, with a maximum at $\sim 7.8 \AA^{-1}$ for the first group and a camel-like split structure with a minimum at $\sim 7.6 \AA^{-1}$ for the second group. All spectra from the second group show considerable similarity to the reference spectrum of the trioctahedral phyllosilicate $\mathrm{Si}_{4}\left(\mathrm{Zn}_{2.4} \mathrm{Mg}_{0.6}\right) \mathrm{O}_{10}(\mathrm{OH})_{2} \cdot \mathrm{nH}_{2} \mathrm{O}$ (ZnKer240), suggesting the predominance of $\mathrm{Zn}$-phyllosilicate in these samples. 
Results from the PCA performed on the complete set of twenty-two EXAFS spectra are given in Table 2 and the first five components (C1-C5) are shown in Fig. 3. C1 to C3 oscillate like real EXAFS spectra and have high signal-to-noise ratios, whereas $\mathrm{C} 4$ and the following components have little meaningful information. IND reached a minimum for three components, suggesting that only $\mathrm{C} 1$ to $\mathrm{C} 3$ are linear combinations of real species spectra (Manceau et al., 2002). The NSS $_{\text {tot }}$ value decreased by $67 \%$ upon addition of $\mathrm{C} 2$ to the one-component $\mathrm{C} 1$ fit, $49 \%$ upon addition of $\mathrm{C} 3$ to the twocomponent $\mathrm{C} 1+\mathrm{C} 2$ fit, but only $22 \%$ and $17 \%$ with $\mathrm{C} 4$ and $\mathrm{C} 5$, respectively. The small decline of $\mathrm{NSS}_{\text {tot }}$ with $\mathrm{C} 4$ and C5 means that these components marginally increased the fit quality, consistent with their low amplitude (Fig. 3). Also, visual examination of all individual fits, and consideration of their NSS values (as low as $0.001-0.032$ with $\mathrm{NSS}_{\text {tot }}=0.010$ ), led to the conclusion that all spectral features were well reproduced with the first three components only. Therefore, $\mathrm{C} 1$ to $\mathrm{C} 3$ were used for target transformation of the reference spectra.

The spectrum of smithsonite $\left(\mathrm{ZnCO}_{3}\right)$ was best reconstructed (NSS $=0.910^{-2}$; Fig. 4). Zinc-rich kerolite $\left(\mathrm{Si}_{4}\left(\mathrm{Zn}_{2.4} \mathrm{Mg}_{0.6}\right) \mathrm{O}_{10}(\mathrm{OH})_{2} \cdot \mathrm{nH}_{2} \mathrm{O}\right.$, $\left.\mathrm{ZnKer} 240\right)$ yielded the best spectral reconstruction $\left(\mathrm{NSS}=1.610^{-2}\right.$ ) among the group of references with $\mathrm{Zn}$ in an octahedral layer (Zn-containing kerolites, Zn-LDH, Zn-substituted montmorillonite). However, the spectrum of $\mathrm{Zn}-\mathrm{LDH}$ is close to that of ZnKer240, as a result of the similarity in the local environment of $\mathrm{Zn}$. In both references, $\mathrm{Zn}$ is surrounded by approximately the same proportion of $\mathrm{Zn}$ and "light" ( $\mathrm{Al}, \mathrm{Mg}$ ) atoms in the nearest cationic shell. The difference between the spectra of the two compounds results from the occurrence of tetrahedral sheets in phyllosilicates, for which Zn-rich kerolite (trioctahedral) and Zn-substituted Redhill montmorillonite (dioctahedral) are used as a proxy. The spectrum of ZnKer240 has an oscillation near $\sim 5.2 \AA^{-1}$ caused by the presence of tetrahedral $\mathrm{Si}$, whereas the spectrum of $\mathrm{Zn}-\mathrm{LDH}$ has only a shoulder at this $k$-value (Schlegel et al., 2001b; Panfili et al., 2005; Schlegel and Manceau, 2006). In the reconstructed spectrum of Zn-LDH (Fig. 4b), an oscillation near $\sim 5.2 \AA^{-1}$, indicative of Zn-phyllosilicate, is clearly present $\left(\mathrm{NSS}=3.510^{-2}\right)$. Therefore, $\mathrm{Zn}-\mathrm{LDH}$ was not retained as an acceptable species for LCF. Target testing of pure Zn-kerolite $\left(\mathrm{Si}_{4} \mathrm{Zn}_{3} \mathrm{O}_{10}(\mathrm{OH})_{2} \cdot \mathrm{nH}_{2} \mathrm{O}, \mathrm{ZnKer} 300\right.$ : NSS $\left.=3.210^{-2}\right)$ was less satisfactory than ZnKer240. 
Similarly, kerolites with lower $\mathrm{Zn} / \mathrm{Mg}$ ratios yielded reconstructions of lower quality relative to ZnKer240 $\left(\mathrm{Si}_{4}\left(\mathrm{Zn}_{0.03} \mathrm{Mg}_{2.97}\right) \mathrm{O}_{10}(\mathrm{OH})_{2} \cdot \mathrm{nH}_{2} \mathrm{O}\right.$, ZnKer003: NSS = $23.610^{-2}$; $\mathrm{Si}_{4}\left(\mathrm{Zn}_{1.35} \mathrm{Mg}_{1.65}\right) \mathrm{O}_{10}(\mathrm{OH})_{2} \cdot \mathrm{nH}_{2} \mathrm{O}$, ZnKer135: NSS $\left.=4.610^{-2}\right)$. The reconstruction of $\mathrm{Zn}$ substituted montmorillonite (ZnMontm: NSS $=16.310^{-2}$ ) was ten times less good than that of ZnKer240. Thus, target testing indicates that Zn-rich kerolite is the most likely Zn-containing layered mineral. The term "kerolite" is used here as a proxy for the general class of ( $\mathrm{Zn}, \mathrm{Mg})$ trioctahedral phyllosilicates, including smectites (e.g. stevensite, saponite) because EXAFS is not sensitive to their layer charge.

Target analysis of the complete database showed that $\mathrm{Zn}$ is tetrahedral in the third identified species. Zn-sorbed ferrihydrite $(\mathrm{ZnFh})$ gave the best visual reconstruction (Fig. 4a), but with a high NSS value $\left(11.810^{-2}\right)$ because the signal is weak. Since this species is less certain, the generic term "tetrahedrally coordinated sorbed Zn" (sorbed ${ }^{\mathrm{IV}} \mathrm{Zn}$ ) will be used in the following to name it, instead of Zn-ferrihydrite. Several other ${ }^{\mathrm{IV}} \mathrm{Zn}$-sorbed species gave similar, or even better, NSS values than $\mathrm{ZnFh}$, but were considered less likely after visual examination of the original and calculated spectra. Of the $\mathrm{Zn}$ phosphates tested, $\mathrm{Zn}$-hydroxylapatite reacted at $\mathrm{pH} 5$ (ZnPhos) was reproduced best $\left(\mathrm{NSS}=8.610^{-2}\right)$, but not accepted because of the phase mismatch of the second oscillation and left side of the third oscillation (Fig. 4b). Also Zn-sorbed montmorillonite (ZnSorbMontm) was rejected due to a phase shift of the second oscillation (NSS = $7.410^{-2}$ ). Of the $\mathrm{Zn}$-organic compounds tested, $\mathrm{Zn}$-humic acid and $\mathrm{Zn}$-fulvic acid complexes $(\mathrm{ZnHu}, \mathrm{ZnFu})$ yielded the best spectral matches $\left(\mathrm{NSS}=6.210^{-2}\right.$ and NSS $=$ $5.910^{-2}$, respectively), but the maximum of the first oscillation was right-shifted in the target transforms $\left(k \sim 4.2 \AA^{-1}\right.$ vs. $\left.3.9 \AA^{-1}\right)$, which is an indication for a difference in $\mathrm{Zn}$ coordination (octahedral vs. tetrahedral; Kirpichtchikova et al., 2006). In addition, the second oscillation was not correctly reproduced.

Willemite, hemimorphite and sphalerite, which were detected in some samples by X-ray diffraction (Table 1), did not pass the target test (Fig. 4b; NSS $=2910^{-2}, 2010^{-2}$ and $7710^{-2}$, respectively). In summary, the three species positively identified are smithsonite, Zn-rich kerolite (as a proxy for high-Zn trioctahedral phyllosilicate) and $\mathrm{Zn}$-ferrihydrite (as a proxy for sorbed ${ }^{\mathrm{IV}} \mathrm{Zn}$ ). 


\subsection{Quantification of $\mathrm{Zn}$ species}

The percentage of $\mathrm{Zn}$ contained in each species was determined by LCF of the twenty-two EXAFS spectra to the reference spectra of smithsonite, ZnKer240 and $\mathrm{Zn}$-ferrihydrite (Fig. 2; Table 3). The precision in the proportion of $\mathrm{Zn}$ contained in each species depends on the amplitude, shape and signal-to-noise ratio of the EXAFS spectra (Sarret et al., 2004). It was estimated here by calculating how much the fit is degraded upon varying the proportions of the reference spectra in the LCF. An increase in NSS of 0.01 had a visible effect on the goodness of fit, as illustrated on Fig. 5a with the bulk spectrum PB30. In this example, the fractional amount of ZnKer240 was varied by $8 \%$ of the total Zn. Fig. 5b shows that this percentage varies with the species, but overall a $10 \%$ precision appears to be a conservative estimate, in agreement with Isaure et al. (2002).

The sum of the fitted fractions varies from 91 to $117 \%$. Deviations from $100 \%$ of the sum of components reflect the combined effects of the accuracy of the method and the precision on the relative amounts of individual species in a mixture. The accuracy depends on how well the standards represent the unknown sample (i.e. slight differences in local environment of $\mathrm{Zn}$ between samples and references), and on errors on the measured (data acquisition) and normalized (data reduction) amplitude of the EXAFS signal (Manceau et al., 2000, 2002). The sums of components for all samples span a range identical $(91 \%)$ or slightly in excess $(117 \%)$ of the precision $(100 \% \pm 10 \%)$, which engenders confidence in our data analysis. The spectra of the bulk LC samples were simulated with a combination of $55-60 \%$ smithsonite and $40-50 \%$ Zn-rich kerolite. The predominance of smithsonite explains the spectral maximum at $\sim 7.8 \AA^{-1}$ noticed previously (Fig. 2). In the bulk PB samples, the fractional amounts of $\mathrm{Zn}$ species range from $<10$ to $\sim 30 \%$ for both smithsonite and sorbed ${ }^{\mathrm{IV}} \mathrm{Zn}$, and from $\sim 60$ to $\sim 110 \%$ for Zn-rich kerolite (Fig. 6). Smithsonite occurs mainly in the lower part of the PB profile (depth $>107 \mathrm{~cm})$, being absent or in trace amounts $(<10 \%)$ in some samples from the upper part. In contrast, sorbed ${ }^{\mathrm{IV}} \mathrm{Zn}$ is below detection limit at the bottom of the PB profile, but amounts to $25-30 \%$ of total $\mathrm{Zn}$ in the first $81 \mathrm{~cm}$ below the surface. Consistent with the small particle size of clays, the proportion of the Zn-rich kerolite pool is systematically higher in the fine $(0-2 \mu \mathrm{m})$ than in the coarse $(0-2 \mathrm{~mm})$ fractions of the LC and PB samples. Hemimorphite was detected by LCF only in the river sediment 
(GE10). This species was not identified by target transformation because it is present in only one spectrum and represents only $24 \%$ of the total $\mathrm{Zn}$ in the sample.

\section{4. $\mathrm{pH}$ and $\mathrm{Zn}$ concentrations in the $0.01 \mathrm{M} \mathrm{CaCl}_{2}$ extracts}

Extractions with $0.01 \mathrm{M} \mathrm{CaCl}_{2}$ were performed on the bulk PB samples. The $\mathrm{pH}\left(\mathrm{CaCl}_{2}\right)$ was between 6.1 and 7.4 , and $\mathrm{Zn}$ concentrations ranged from $0.03 \mathrm{mM}$ to $0.64 \mathrm{mM}$. Fig. $6 \mathrm{c}-\mathrm{d}$ shows that the variations in sediment $\mathrm{pH}$ follow the variations in the amounts of the $\mathrm{Zn}$-smithsonite pool. Sediments with $\mathrm{pH}\left(\mathrm{CaCl}_{2}\right)>7.0$ contain $\sim 1500$ $3000 \mathrm{mg} / \mathrm{kg} \mathrm{Zn}$ in smithsonite (i.e. 20-30 \% of total Zn), while this pool is below $500 \mathrm{mg} / \mathrm{kg}(<10 \%$ of total $\mathrm{Zn})$ when $\mathrm{pH}\left(\mathrm{CaCl}_{2}\right)<7.0$. The correlation between $\mathrm{pH}$ and smithsonite abundance is further supported by results from the $0.01 \mathrm{M} \mathrm{CaCl}_{2}$ extractions. When $\mathrm{pH}\left(\mathrm{CaCl}_{2}\right)>7.0$, the concentration of aqueous $\mathrm{Zn}$ corresponds to that in equilibrium with smithsonite (Fig. 7), suggesting that the quantity of Zn dissolved in pore water is controlled by smithsonite solubility. When $\mathrm{pH}\left(\mathrm{CaCl}_{2}\right)<7.0$, the solutions are undersaturated with respect to smithsonite, but oversaturated or near saturation with respect to Zn-kerolite. Thus, chemical extraction data and solubility calculations are consistent with the mineralogy of the two crystalline $\mathrm{Zn}$ phases determined by EXAFS.

\section{DISCUSSION}

\subsection{Zn species and uncertainties in their identification}

Three $\mathrm{Zn}$ species were used in LCF: smithsonite, Zn-rich kerolite and Znferrihydrite. Smithsonite is primary in origin, whereas $\mathrm{Zn}$-rich kerolite and $\mathrm{Zn}$ ferrihydrite are secondary $\mathrm{Zn}$ species. The presence of smithsonite in the two sediment profiles can be explained by the fact that this mineral was mined and smelted upstream in La Calamine. Mineral particles were transported by the river and deposited on the floodplain. Smithsonite was identified previously in dredged sediments by Ndiba et al. (2008) using EXAFS. Sphalerite and franklinite were the main mineral contaminants in other EXAFS studies (Manceau et al., 2000; Isaure et al., 2002, 2005; Roberts et al., 2002; Scheinost et al., 2002; Juillot et al., 2003; Sarret et al., 2004; Nachtegaal et al., 2005). Formation of smithsonite as a secondary species is thermodynamically and kinetically 
unlikely (Schindler et al., 1969). The usual Zn carbonate species formed in calcareous settings with high $\mathrm{Zn}$ load is hydrozincite $\left(\mathrm{Zn}_{5}(\mathrm{OH})_{6}\left(\mathrm{CO}_{3}\right)_{2}\right)$ (Jacquat et al., 2008), by virtue of the higher stability of hydroxylated mineral species at the Earth's surface.

Zinc-rich kerolite-like phyllosilicate is the major form of $\mathrm{Zn}$ in most samples. This species has been identified previously in contaminated soils and sediments, and was derived from the in-situ weathering of primary minerals (Manceau et al., 2000; Panfili et al., 2005; Kirpichtchikova et al., 2006; Jacquat et al., 2008). Because of the spectral similarities between ZnKer240, ZnKer300 and Zn-LDH, the mathematical solution obtained by LCF may not be unique. This effect is exemplified with the spectrum of the 0-2 $\mu \mathrm{m}$ fraction of LC04 (Fig. 8). A good fit was obtained with ZnKer240 only (NSS = $1.5810^{-2}$; Table 3 ). Adding minor Zn-LDH did not improve significantly the fit quality $\left(\mathrm{NSS}=1.5410^{-2}\right)$. However, combining ZnKer300 and Zn-LDH in a 1/1 ratio decreased NSS by more than $50 \%$ (NSS $=0.7410^{-2}$ ). In the three compounds, octahedral $\mathrm{Zn}$ is surrounded by $\mathrm{Zn}$ and "light" atoms (Al, $\mathrm{Mg}$ ) in the second shell, but not in the same proportions. In $\mathrm{ZnKer} 300\left(\mathrm{Si}_{4} \mathrm{Zn}_{3} \mathrm{O}_{10}(\mathrm{OH})_{2} \cdot \mathrm{nH}_{2} \mathrm{O}\right), \mathrm{Zn}$ has six next-nearest $\mathrm{Zn}$ atoms, and in $\mathrm{ZnKer} 240\left(\mathrm{Si}_{4}\left(\mathrm{Zn}_{2.4} \mathrm{Mg}_{0.6}\right) \mathrm{O}_{10}(\mathrm{OH})_{2} \cdot \mathrm{nH}_{2} \mathrm{O}\right), 4.8 \mathrm{Zn}$ and $1.2 \mathrm{Mg}$ on average. In $\mathrm{Zn}-$ $\mathrm{LDH}\left(\mathrm{Zn}_{2} \mathrm{Al}(\mathrm{OH})_{6} \mathrm{Cl}\right), \mathrm{Zn}$ is surrounded either by $4 \mathrm{Zn}$ and $2 \mathrm{Al}$ on average if the cations are distributed at random in the octahedral layer, or by $3 \mathrm{Zn}$ and $3 \mathrm{Al}$ exactly if their distribution is ordered (Bellotto et al., 1996). Thus, if $50 \%$ of $\mathrm{Zn}$ is in $\mathrm{ZnKer300}$ and $50 \%$ in $\mathrm{Zn}-\mathrm{LDH}, \mathrm{Zn}$ is surrounded on average by $4.5-5.0 \mathrm{Zn}$ and $1.0-1.5 \mathrm{Al}$, that is by approximately the same number of "heavy" and "light" (Al, Mg) atoms as in ZnKer240, explaining why EXAFS cannot differentiate between this mixture and pure ZnKer240.

Returning to experimental data, the effect of this indetermination was tested for all twenty-two spectra. In all cases, a better fit was obtained with a mixture of ZnKer300 and Zn-LDH instead of ZnKer240, with 1/3 $<$ ZnKer300 / Zn-LDH $<3 / 2$. However, the hypothesis of two layered $\mathrm{Zn}$ species seems unlikely for three reasons. First, Zn-LDH was not acceptably reproduced by target transformation. Second, $\mathrm{Zn}-\mathrm{Mg}$ kerolites are less soluble than $\mathrm{ZnKer300,} \mathrm{otherwise} \mathrm{Zn}$ would not mix with $\mathrm{Mg}$ at the atomic scale to form a solid-solution between the Mg- and Zn-pure end-members (Manceau et al., 2000; Panfili et al., 2005). Third, Zn-Mg kerolites with the same (ZnKer240) and other (ZnKer210, ZnKer135, ZnKer070) average stoichiometries were identified previously in 
soils and sediments by micro-EXAFS, resulting in a more definitive identification (Isaure et al., 2002, 2005; Panfili et al., 2005; Kirpichtchikova et al., 2006; Jacquat et al., 2008). Therefore, the predominance of $\mathrm{Zn}$ phyllosilicate is most likely, but spectral interference with minor fractions of Zn-LDH can not be ruled out.

Out of the three main $\mathrm{Zn}$ species identified in this study, Zn sorbed on ferrihydrite is the least certain. This species has been identified many times in contaminated matrices, and its formation from the weathering of $\mathrm{Zn}$ and Fe particles is largely expected in this type of environment. However, the good reconstruction of the $\mathrm{ZnFh}$ spectrum by target transformation does not imply that this species exists, because tetrahedral $\mathrm{Zn}$ species generally yield similar EXAFS spectra owing to the intensity of the signal from the first oxygen shell (Sarret et al., 2004; Diesing et al., 2008; Jacquat et al., 2008). For instance, $\mathrm{Zn}$-sorbed organic matter is very common in soils and sediments, and can hardly be differentiated from Zn-sorbed ferrihydrite by powder EXAFS.

\subsection{Age of the overbank sediments in Plombières}

The overbank sediments near Plombières received metals from the different mining and smelting centres along the river, but dominantly from La Calamine (oxidized $\mathrm{Zn}$ ores) and Plombières ( $\mathrm{Pb}-\mathrm{Zn}$ sulphides) (Fig. 1). The large-scale activities in Plombières started in 1844. At that time, the La Calamine mine and smelter were already in full operation for several decades ( $\mathrm{Zn}$ ore production above 4000 ton/year since 1825; Dejonghe et al., 1993). Elevated Pb concentrations ( $>2000 \mathrm{mg} / \mathrm{kg}$ ) in the overbank sediments most likely result from the $\mathrm{Pb}-\mathrm{Zn}$ mining and smelting in Plombières, thus the vertical $\mathrm{Pb}$ distribution pattern (Fig. 6b) allows differentiation between sediments deposited before and after 1844 . Since the $\mathrm{Pb}$ profile shows a marked discontinuity at $\sim 114 \mathrm{~cm}$ depth, $\mathrm{Zn}$ at deeper depth originates in all likelihood mainly from La Calamine, and $\mathrm{Zn}$ above this limit from the two production areas (Fig. 6). The validity of the sediment dating at $\sim 114 \mathrm{~cm}$ is verified by the correlation between the upper part of the $\mathrm{Pb}$ profile $(\sim 25-114 \mathrm{~cm})$ and the yearly production of galena from the Plombières mine over the 1844-1882 period (Dejonghe et al., 1993; Fig. 6b).

Delineation of the sediments deposited before the industrial period $(<1806)$ and after the closure of the major mines (1884) is less evident. The elevated $\mathrm{Zn}$ and $\mathrm{Pb}$ 
concentrations at the bottom of the profile, including the gravel- and clay-rich layer deposited during the Pleistocene (sample PB01; Van de Westeringh, 1980), probably result from the weathering of ore deposits exposed to the surface and from ancient smallscale mining activities. Smelting operations after the closure of the mines, weathering and erosion of waste dumps, and remobilization of upstream contaminated sediments, explain the high $\mathrm{Zn}$ and $\mathrm{Pb}$ concentrations near the surface. A similar approach to date the overbank sediments of the Geul river using $\mathrm{Zn}$ and $\mathrm{Pb}$ concentrations was applied by Swennen et al. (1994) and Stam $(1999,2002)$.

\subsection{Downstream change in $\mathrm{Zn}$ speciation resulting from La Calamine mining and smelting}

The overbank sediments near La Calamine (LC04, LC07, LC09) and the bottom sediments near Plombières (PB02 to PB12) were both contaminated by oxidized Zn minerals. Smithsonite is, however, proportionally much more abundant in the upstream section (LC samples) of the river ( 55-60\% of total $\mathrm{Zn}$ ), where the samples are richer in Zn (29000-69000 mg/kg), than in the downstream section $(<30 \%)$, where the samples have less than $12000 \mathrm{mg} / \mathrm{kg} \mathrm{Zn}$ (Table 3). This positive correlation between smithsonite fraction and total $\mathrm{Zn}$ concentration suggests that the ratio of smithsonite to $\mathrm{Zn}$ phyllosilicate in the two sediment columns is controlled by the dissolution rate of the carbonate, since dilution of $\mathrm{Zn}$ by uncontaminated sediment would preserve the proportion of smithsonite relative to the total amount of $\mathrm{Zn}$, and the $\mathrm{pH}$ does not vary significantly between the two sites (Table 1). Thus, starting from a lower total amount of smithsonite in the downstream sediments, a constant rate of conversion of smithsonite would result in a larger proportion of secondary Zn species at Plombières. Assuming the downstream particles were smaller than at La Calamine, the effect would be enhanced because the dissolution rate of smaller particles is known to be faster.

\subsection{Vertical distribution of smithsonite in the Plombières profile}

The upper part of the overbank sediments near Plombières (>114 cm; Fig. 6) was contaminated by mining and smelting of $\mathrm{Pb}-\mathrm{Zn}$ sulphides, in addition to oxidized $\mathrm{Zn}$ ores. The amount of $\mathrm{Zn}$ as smithsonite decreases from $\sim 1500-3000 \mathrm{mg} / \mathrm{kg}(\sim 20-30 \%$ of total 
$\mathrm{Zn})$ in the deeper sediment $(107-183 \mathrm{~cm})$ to $<500 \mathrm{mg} / \mathrm{kg}(<10 \%$ of total $\mathrm{Zn})$ in the upper part $(<81 \mathrm{~cm})$. Likely, the upper sediments received less source material from $\mathrm{La}$ Calamine because of lower emissions, as attested by the decrease in $\mathrm{Zn}$ concentration in the sediment profile near La Calamine from $47000 \mathrm{mg} / \mathrm{kg}$ at $100 \mathrm{~cm}$ depth to 10000 $\mathrm{mg} / \mathrm{kg}$ in subsurface (data not shown). Also, the amount of smithsonite at Plombières is correlated with $\mathrm{pH}\left(\mathrm{CaCl}_{2}\right)$, as noticed previously (section 3.4). Fig. 6c-d shows that the abrupt diminution of smithsonite at the onset of the $\mathrm{Pb}-\mathrm{Zn}$ contamination is accompanied by a drop in $\mathrm{pH}$ from 7.3-7.4 to 6.4-6.8, which is probably related to the oxidative dissolution of sulphides. Sphalerite and galena were mined in Plombières and other locations in the Geul catchment (Dejonghe, 1993, 1998) and were most probably transported by the river and deposited on the floodplain. The elevated concentrations of $\mathrm{Pb}$ and $\mathrm{As}$ in the upper $\mathrm{PB}$ sediments originate undoubtedly from the sulphide mining acitivities in Plombières, and the presence of sphalerite in the present-day bedload (Table 1) confirms the transport of sulphides by the river. When exposed to oxygen, oxidation and dissolution of sulphides occurs, as shown for example by Isaure et al. (2005), Panfili et al. (2005) and Schuwirth et al. (2007). This chemical reaction results in acidification of the pore water (Smith, 2004), analogous to the processes of acid mine drainage and acid sulphate soils. Here, the decrease in $\mathrm{pH}$ is relatively small (at most one unit), because of the large $\mathrm{pH}$ buffering capacity of carbonates. Thus, acidic dissolution of smithsonite likely contributed also to the scarcity of this mineral at the top of the sediment column. Similarly, the pre-industrial sediments PB02 and PB03 (193-206 cm) have a low smithsonite content and $\mathrm{pH}$. The lower $\mathrm{pH}$ can be explained by the higher organic matter content in the sediments deposited before the large-scale deforestation of the Middle Ages (Van de Westeringh, 1980). In summary, the present speciation of $\mathrm{Zn}$ is well explained by the nature of the ore minerals that were mined and smelted in this area at the time of deposition. There is no evidence of an effect of the absolute age of the overbank sediments on the speciation of $\mathrm{Zn}$ over the last 200 years.

\subsection{Abundance of $\mathrm{Zn}$-phyllosilicate}

The overbank sediments of the Geul river have the highest abundance of Zn-rich phyllosilicate identified so far in natural settings. This species was even the only one 
detected in some samples (Table 3). Likely, willemite and hemimorphite were a source of dissolved $\mathrm{Zn}$ and Si. These $\mathrm{Zn}$-silicates were mined from the ore deposit of La Calamine, together with smithsonite. The carbonate was dominant near the surface, whereas willemite was the major mineral at $>80 \mathrm{~m}$ depth (reached in 1865; Dejonghe et al., 1993). Hemimorphite was the least abundant of the three ore species. Despite their abundance in the ore deposit, the two primary $\mathrm{Zn}$ silicates are today minor $\mathrm{Zn}$ species in the overbank sediments of the Geul river. The preservation of smithsonite in proportions up to $60 \%$ of total $\mathrm{Zn}$ suggests that willemite and hemimorphite were dissolved to a large extent in the overbank sediments. Thus, their weathering may have promoted the formation of $\mathrm{Zn}$ phyllosilicate. This interpretation cannot be supported by thermodynamic stability calculations because accurate solubility products are lacking for hemimorphite (Brugger et al., 2003; McPhail et al., 2003, 2006) and Zn-rich kerolite (Manceau et al., 2000). Also, the solubility of Zn-LDH, an alternative secondary precipitate, is not well known (Jacquat et al., 2008), further complicating the assessment of the most stable $\mathrm{Zn}$ phase at various environmental conditions ( $\mathrm{pCO}_{2}, \mathrm{Si}$ and $\mathrm{Al}$ concentration). However, similar abundance of Zn-phyllosilicate was observed by Manceau et al. (2000) in soils contaminated with willemite and hemimorphite, whereas Zn-phyllosilicates are generally less abundant $(<$ $50 \%$ of total $\mathrm{Zn}$ ) in soils contaminated by other emission sources (e.g. Panfili et al., 2005; Kirpichtchikova et al., 2006).

The La Calamine ores were cemented with the trioctahedral Zn-phyllosilicate sauconite $\left(\mathrm{Na}_{0.3} \mathrm{Zn}_{3}(\mathrm{Si}, \mathrm{Al})_{4} \mathrm{O}_{10}(\mathrm{OH})_{2} .4\left(\mathrm{H}_{2} \mathrm{O}\right)\right.$; Coppola et al., 2008). This mineral has a negative layer charge because of substitutions of $\mathrm{Al}$ for $\mathrm{Si}$ in the tetrahedral sheet, and thus belongs to the smectite group, in contrast to kerolite, which is a disordered hydrated talc with no or little swelling properties (Brindley et al., 1977; Brindley and Brown, 1980). The two phyllosilicates can have the same ( $\mathrm{Zn}, \mathrm{Mg}$ ) stoechiometry (Petit et al., 2008), which prevents them from being differentiated by powder EXAFS. Since Zn was contained mainly in smithsonite, willemite and hemimorphite in the La Calamine ores, and only for a minor amount in sauconite (Dejonghe et al., 1993; Coppola et al., 2008), the overbank sediments presumably also contained much more of the primary minerals than sauconite at the time of deposition. The present-day scarcity of willemite and hemimorphite therefore suggests that inherited sauconite represents only a small fraction 
of the Zn-kerolite pool, and that the Zn-phyllosilicate is for the most part neoformed. However, since the layer charge of the Zn-phyllosilicate is unknown, the term kerolitelike is more generic, and thus more appropriate.

\section{CONCLUSION}

Zinc speciation was determined in the overbank sediments of the Geul river, which were contaminated by historical mining and smelting of oxidized $\mathrm{Zn}$ ores (smithsonite, willemite, hemimorphite) and $\mathrm{Pb}-\mathrm{Zn}$ sulphides. EXAFS shows that $\mathrm{Zn}$ occurs predominantly in the primary mineral smithsonite, as $\mathrm{Zn}$-containing trioctahedral phyllosilicate, and as surface ${ }^{\mathrm{IV}} \mathrm{Zn}$ species sorbed to sediment constituents (e.g. ferrihydrite, organic matter). Smithsonite is persistent in sediments with $\mathrm{pH}\left(\mathrm{CaCl}_{2}\right)>7.0$, which were contaminated by oxidized $\mathrm{Zn}$ ores only. At the onset of additional contamination by $\mathrm{Pb}-\mathrm{Zn}$ sulphide mining and smelting, (i) the $\mathrm{Zn}$-smithsonite pool decreases from $\sim 1500-3000 \mathrm{mg} / \mathrm{kg} \mathrm{Zn}$ to $<500 \mathrm{mg} / \mathrm{kg} \mathrm{Zn}$, (ii) the sorbed ${ }^{\mathrm{IV}} \mathrm{Zn}$ pool rises from undetectable to $\sim 1000-3500 \mathrm{mg} / \mathrm{kg} \mathrm{Zn}$, and (iii) the $\mathrm{pH}\left(\mathrm{CaCl}_{2}\right)$ decreases from 7.37.4 to $6.4-6.8$. These changes probably result from the oxidation of sulphide minerals, an acid-producing process which promotes the dissolution of smithsonite and other carbonates, and from the adsorption of the dissolved $\mathrm{Zn}^{2+}$ as surface complexes. The primary minerals willemite and hemimorphite were not identified by EXAFS in the overbank sediments. The weathering of these two silicates presumably led to the formation of Zn-phyllosilicate. The abundance of Zn-phyllosilicate in the sediments covering 200 years of deposition history attests to the stability of this $\mathrm{Zn}$ phase, as long as the current environmental conditions (including the near neutral $\mathrm{pH}$ ) are preserved. Changes in the soil chemistry, such as acidification, could cause the release of $\mathrm{Zn}^{2+}$ by dissolution of the $\mathrm{Zn}$-phyllosilicate phase. However, this process is unlikely to occur as long as there are carbonates to buffer the $\mathrm{pH}$. This study shows how information on contamination history and EXAFS can be combined to understand the weathering process of primary $\mathrm{Zn}$ minerals in overbank sediments. 


\section{Acknowledgments}

The authors thank Drs. F. Panfili, A. Scheinost, A. Voegelin and their co-workers for providing EXAFS spectra of $\mathrm{Zn}$ references. The staff of beamline BM26A (DUBBLE) and Dr. G. Cornelis are acknowledged for the help with EXAFS data acquisition. We thank the NWO (Netherlands Organisation for Scientific Research) and FWO-Vlaanderen (Fund for Scientific Research-Flanders) for the provision of beamtime at DUBBLE/ESRF and for the financial support. A. Van Damme and F. Degryse acknowledge the FWOVlaanderen for a position as research assistant and postdoctoral researcher, respectively. This manuscript benefitted from the constructive remarks of three anonymous reviewers. 


\section{REFERENCES}

Allison J. D., Brown D. S. and Novo-Gradac K. J. (1991) MINTEQA2/PRODEFA2, A Geochemical Assessment Model for Environmental Systems. U.S. Environmental Protection Agency.

Bellotto M., Rebours B., Clause O., Lynch J., Bazin D. and Elkaïm E. (1996) A reexamination of hydrotalcite crystal chemistry. J. Phys. Chem. 100: 8527-8534.

Brindley G. W. and Brown G. (1980) Crystal structures of clay minerals and their X-ray identification. Mineralogical Society, London.

Brindley G. W., Bish D. L. and Wan H.-M. (1977) The nature of kerolite, its relation to talc and stevensite. Mineral. Mag. 41: 443-452.

Brugger J., McPhail D. C., Wallace M. and Waters J. (2003) Formation of Willemite in Hydrothermal Environments. Econ. Geol. 98: 819-835.

Coppola V., Boni M., Gilg H. A., Balassone G. and Dejonghe L. (2008) The "calamine" nonsulfide $\mathrm{Zn}-\mathrm{Pb}$ deposits of Belgium: Petrographical, mineralogical and geochemical characterization. Ore Geol. Rev. 33, 187-210.

D'Amore J. J., Al-Abed S. R., Scheckel K. G. and Ryan J. A. (2005) Methods for speciation of metals in soils: A review. J. Environ. Qual. 34: 1707-1745.

Degryse F., Broos K., Smolders E. and Merckx R. (2003) Soil solution concentration of $\mathrm{Cd}$ and $\mathrm{Zn}$ can be predicted with a $\mathrm{CaCl}_{2}$ soil extract. Eur. J. Soil Sci. 54: 149-158.

Dejonghe L. (1998) Zinc-lead deposits of Belgium. Ore Geol. Rev. 12, 329-354.

Dejonghe L., Ladeuze F. and Jans, D. (1993) Atlas des gisements plombo-zincifères du Synclinorium de Verviers (Est de la Belgique). Mémoires pour servir à l'Explication des Cartes Géologiques et Minières de la Belgique 33, 1-483.

Diesing W. E., Sinaj S., Sarret G., Manceau A., Flura T., Demaria P., Siegenthaler A., Sappin-Didier V. and Frossard E. (2008) Zinc speciation and isotopic exchangeability in soils polluted with heavy metals. Eur. J. Soil Sci. 59, 716-729.

Horckmans L., Swennen R. and Deckers J. (2007) Retention and release of Zn and Cd in spodic horizons as determined by $\mathrm{pH}_{\text {stat }}$ analysis and single extractions. Sci. Total Environ. 376: 86-99. 
Houba V. J. G., Lexmond Th. M., Novozamsky I. and van der Lee J. J. (1996) State of the art and future developments in soil analysis for bioavailability assessment. Sci. Total Environ., 178: 21-28.

Isaure M.-P., Laboudigue A., Manceau A., Sarret G., Tiffrau C., Trocellier P., Lamble G. M., Hazemann J. L. and Chateigner D. (2002) Quantitative Zn speciation in a contaminated dredged sediment by $\mu$-PIXE, $\mu$-SXRF, EXAFS spectroscopy and principal component analysis. Geochim. Cosmochim. Acta 66, 1549-1567.

Isaure M.-P., Manceau A., Geoffroy N., Laboudigue A., Tamura N. and Marcus M. A. (2005) Zinc mobility and speciation in soil covered by contaminated dredged sediment using micrometer-scale and bulk-averaging X-ray fluorescence, absorption and diffraction techniques. Geochim. Cosmochim. Acta 69, 1173-1198.

Jacquat O., Voegelin A., Villard A., Marcus M. A. and Kretzschmar R. (2008) Formation of Zn-rich phyllosilicate, Zn-layered double hydroxide and hydrozincite in contaminated calcareous soils. Geochim. Cosmochim. Acta 72, 5037-5054.

Jacquat O., Voegelin A., Kretzschmar R. (2009) Soil properties controlling Zn speciation and fractionation in contaminated soils. Geochim. Cosmochim. Acta 73, 52565272.

Juillot F., Morin G., Ildefonse P., Trainor T. P., Benedetti M., Galoisy L., Calas G. and Brown G. E. (2003) Occurrence of $\mathrm{Zn} / \mathrm{Al}$ hydrotalcite in smelter-impacted soils from northern France: evidence from EXAFS spectroscopy and chemical extractions. Am. Mineral. 88, 509-526.

Kirpichtchikova T. A., Manceau A., Spadini L., Panfili F., Marcus M. A. and Jacquet T. (2006) Speciation and solubility of heavy metals in contaminated soil using X-ray microfluorescence, EXAFS spectroscopy, chemical extraction, and thermodynamic modeling. Geochim. Cosmochim. Acta 70, 2163-2190.

Konert M. and Vandenberghe J. (1997) Comparison of laser grain size analysis with pipette and sieve analysis: a solution for the underestimation of the clay fraction. Sedimentology 44, 523-535.

Kucha H., Martens A., Ottenburgs R., De Vos W. and Viaene W. (1996) Primary minerals of $\mathrm{Zn}-\mathrm{Pb}$ mining and metallurgical dumps and their environmental behavior at Plombières, Belgium. Environ. Geol. 27: 1-15. 
Leenaers H. (1989) The dispersal of metal mining wastes in the catchment of the river Geul (Belgium- the Netherlands). Netherlands Geographical Studies 102: 1-200.

Malinowski E. R. (1977) Determination of the number of factors and the experimental error in a data matrix. Anal. Chem. 49: 612-617.

Malinowski E.R. (1978) Theory of error for target factor analysis with applications to mass spectrometry and nuclear magnetic resonance spectrometry. Anal. Chim. Acta 103, 339-354.

Manceau A., Bonnin D., Stone W. E. E. and Sanz J. (1990) Distribution of Fe in the octahedral sheet of trioctahedral micas by polarized EXAFS. Phys. Chem. Miner. 17: $363-370$.

Manceau A., Boisset M. C., Sarret G., Hazemann J. L., Mench M., Cambier Ph. and Prost R. (1996) Direct determination of lead speciation in contaminated soils by EXAFS spectroscopy. Environ. Sci. Technol., 30: 1540-1552.

Manceau A., Lanson B., Schlegel M. L., Harge J. C., Musso M., Eybert-Berard L., Hazemann J. L., Chateigner D. and Lamble G. M. (2000) Quantitative Zn speciation in smelter-contaminated soils by EXAFS spectroscopy. Am. J. Sci. 300, 289-343.

Manceau A., Marcus M. A. and Tamura N. (2002) Quantitative speciation of heavy metals in soils and sediments by synchrotron X-ray techniques. In Applications of Synchrotron Radiation in Low-Temperature Geochemistry and Environmental Science (eds. P. Fenter, S. Sutton, M. Rivers and N. C. Sturchio). Rev. Mineral. Geochem. 49, 341-428.

Manceau A., Tommaseo C., Rihs S., Geoffroy N., Chateigner D., Schlegel M. L., Tisserand D., Marcus M. A., Tamura N. and Zueng-Sang C. (2005) Natural speciation of $\mathrm{Mn}, \mathrm{Ni}$, and $\mathrm{Zn}$ at the micrometer scale in a clayey paddy soil using X-ray fluorescence, absorption, and diffraction. Geochim. Cosmochim. Acta 60, 4007-4034.

Manceau A. and Matynia A. (2010) The nature of $\mathrm{Cu}$ bonding to natural organic matter. Geochim. Cosmochim. Acta, in press. 
Marcus M. A., MacDowell A. A., Celestre R., Manceau A., Miller T., Padmore H. A. and Sublett R. E. (2004) Beamline 10.3.2 at ALS: a hard X-ray microprobe for environmental and materials sciences. J. Synchrotron Radiat. 11: 239-247

McPhail D. C., Summerhayes E., Welch S. and Brugger J. (2003) The geochemistry and mobility of zinc in the regolith. In Advances in Regolith (ed. I.C. Roach). CRC LEME, Bentley. pp. 287-291.

McPhail D. C., Summerhayes E., Jayaratne V. and Christy A. (2006) Hemimorphite solubility and stability of low-T zinc minerals. Geochim. Cosmochim. Acta 70: A414.

Miller J. R. and Orbock Miller S. M. (2007) Contaminated Rivers: A GeomorphologicalGeochemical Approach to Site Assessment and Remediation. Springer, Dordrecht. Nachtegaal M., Marcus M. A., Sonke J. E., Vangronsveld J., Livi K. J. T., Van der Lelie D. and Sparks D. L. (2005) Effects of in situ remediation on the speciation and bioavailability of zinc in a smelter contaminated soil. Geochim. Cosmochim. Acta 69, 4649-4664.

Ndiba P., Axe L. and Boonfueng T. (2008) Heavy metal immobilization through phosphate and thermal treatment of dredged sediments. Environ. Sci. Technol. 42: 920-926.

Nelson D. W. and Sommers L. E. (1982) Total carbon, organic carbon, and organic matter. In Methods of soil analysis, Part 2: chemical and microbiological properties (eds. A. L. Page, R. H. Miller and D. R. Keeney). American Society of Agronomy, Madison. pp. 539-579.

Newville M. (2001) IFEFFIT: interactive XAFS analysis and FEFF fitting. $J$. Synchrotron Radiat. 8, 322-324.

Nikitenko S., Beale A. M., van der Eerden A. M. J., Jacques S. D. M., Leynaud O., O'Brien M. G., Detollenaere D., Kaptein R., Weckhuysen B. M. and Bras W. (2008) Implementation of a combined SAXS/WAXS/QuEXAFS set-up for timeresolved in situ experiments. J. Synchrotron Radiat. 15: 632-640.

Ottesen R. T., Bogen J., Bolviken B. and Volden T. (1989) Overbank sediment: a representative sample medium for regional geochemical mapping. J. Geochem. Explor. 32, 257-277. 
Panfili F. R., Manceau A., Sarret G., Spadini L., Kirpichtchikova T., Bert V., Laboudigue A., Marcus M. A., Ahamdach N. and Libert M. F. (2005) The effect of phytostabilization on $\mathrm{Zn}$ speciation in a dredged contaminated sediment using scanning electron microscopy, X-ray fluorescence, EXAFS spectroscopy, and principal components analysis. Geochim. Cosmochim. Acta 69, 2265-2284.

Petit S., Righi D. and Decarreau A. (2008) Transformation of synthetic Zn-stevensite to Zn-talc induced by the Hofmann-Klemen effect. Clays Clay Miner. 56: 645-654.

Quevauviller, Ph. (1998) Operationally defined extraction procedures for soil and sediment analysis I. Standardization. Trends Anal. Chem. 17, 289-298.

Ravel B. and Newville M. (2005) Athena, Artemis, Hephaestus: data analysis for X-ray absorption spectroscopy using IFEFFIT. J. Synchrotron Radiat. 12, 537-541.

Ressler T., Wong J., Roos J. and Smith I. L. (2000) Quantitative speciation of Mnbearing particulates emitted from autos burning (methylcyclopentadienyl)manganese tricarbonyl-added gasolines using XANES spectroscopy. Environ. Sci. Technol., 34: 950-958.

Roberts D. R., Scheinost A. C. and Sparks D. L. (2002) Zinc speciation in a smeltercontaminated soil profile using bulk and microspectroscopic techniques. Environ. Sci. Technol. 36, 1742-1750.

Sarret G., Saumitou-Laprade P., Bert V., Proux O., Hazemann J. L., Traverse A., Marcus M. A. and Manceau A. (2002) Forms of $\mathrm{Zn}$ accumulated in the hyperaccumulator Arabidopsis halleri. Plant Physiol. 130, 1815-1826.

Sarret G., Balesdent J., Bouziri L., Garnier J. M., Marcus M. A., Geoffroy N., Panfili F. and Manceau A. (2004) Zn speciation in the organic horizon of a contaminated soil by micro-X-ray fluorescence, micro- and powder-EXAFS spectroscopy, and isotopic dilution. Environ. Sci. Technol. 38, 2792-2801.

Scheinost A. C., Kretzschmar R., Pfister S. and Roberts D. R. (2002) Combining selective sequential extractions, $\mathrm{X}$-ray absorption spectroscopy, and principal component analysis for quantitative zinc speciation in soil. Environ. Sci. Technol. 36, 5021-5028. 
Schindler P., Reinert M. and Gamsjäger H. (1969) Löslichkeitskonstanten und freie Bildungsenthlapien von $\mathrm{ZnCO}_{3}$ und $\mathrm{Zn}_{5}(\mathrm{OH})_{6}\left(\mathrm{CO}_{3}\right)_{2}$ bei $25^{\circ} \mathrm{C}$. Helv. Chim. Acta 52, 2327-2332.

Schlegel M. L. and Manceau A. (2006) Evidence for the nucleation and epitaxial growth of Zn phyllosilicate on montmorillonite. Geochim. Cosmochim. Acta 70, 901-917.

Schlegel M. L., Manceau A., Charlet L. and Hazemann J. L. (2001a) Adsorption mechanisms of $\mathrm{Zn}$ on hectorite as a function of time, $\mathrm{pH}$, and ionic strength. Am. J. Sci. 301, 798-830.

Schlegel M. L., Manceau A., Charlet L., Chateigner D. and Hazemann J. L. (2001b) Sorption of metal ions on clay minerals. III. Nucleation and epitaxial growth of Zn phyllosilicate on the edges of hectorite. Geochim. Cosmochim. Acta 65, 41554170.

Schuwirth N., Voegelin A., Kretzschmar R. and Hofmann T. (2007) Vertical distribution and speciation of trace metals in weathering flotation residues of a zinc/lead sulfide mine. J. Environ. Qual. 36, 61-69.

Smith J. (2004) Chemical changes during oxidation of iron monosulfide-rich sediments. Aust. J. Soil Res. 42: 659-666.

Stam M. H. (1999) The dating of fluvial deposits with heavy metals, Pb-210 Cs-137 in the Geul catchment (The Netherlands). Phys. Chem. Earth. PT B 24: 155-160.

Stam M. H. (2002) Effects of land-use and precipitation changes on floodplain sedimentation in the nineteenth and twentieth centuries (Geul River, The Netherlands). Spec. Publ. IAS 32: 251-267.

Swennen R. and Viaene W. (1990) Lithogeochemical patterns around Pb-Zn mineralizations in Dinantian carbonate rocks of (eastern) Belgium. Mineral. Deposita 25, 251-261.

Swennen R., Van Keer I. and De Vos W. (1994) Heavy metal contamination in overbank sediments of the Geul river (East Belgium): Its relation to former $\mathrm{Pb}-\mathrm{Zn}$ mining activities. Environ. Geol. 24, 12-21.

Van de Westeringh W. (1980) Soils and their geology in the Geul Valley. In Soil conditions, soil carbonates and former vegetation in the Geul valley from Gulpen 
to Meerssen (South Limburg, The Netherlands) (ed. W. Van de Westeringh). Mededelingen Landbouwhogeschool Wageningen 80, 1-25.

Van Herreweghe S., Swennen R., Cappuyns V. and Vandecasteele C. (2002) Chemical associations of heavy metals and metalloids in contaminated soils near former ore treatment plants: a differentiated approach with emphasis on pHstat-leaching. $J$. Geochem. Explor. 76: 113-138.

Voegelin A., Pfister S., Scheinost A. C., Marcus M. A. and Kretzschmar R. (2005) Changes in zinc speciation in field soil after contamination with zinc oxide. Environ. Sci. Technol. 39, 6616-6623.

Wasserman S. R., Allen P. G., Shuh D. K., Bucher J. J. and Edelstein N. M. (1999) EXAFS and principal component analysis: a new shell game. J. Synchrotron Radiat. 6: 284-286. 
Table 1: Physico-chemical characteristics of sediment samples.

\begin{tabular}{|c|c|c|c|c|c|c|c|}
\hline \multirow{3}{*}{$\begin{array}{l}\text { Sampling site } \\
\text { Sediment type } \\
\text { Depth interval }\end{array}$} & \multirow{3}{*}{$\begin{array}{c}\text { La Calamine (LC) } \\
\text { Overbank } \\
\text { sediment } \\
0-228 \mathrm{~cm} \\
\end{array}$} & \multicolumn{5}{|c|}{ Plombières (PB) } & \multirow{3}{*}{$\begin{array}{c}\text { Border B-Nl } \\
\text { River } \\
\text { sediment } \\
-\end{array}$} \\
\hline & & \multicolumn{5}{|c|}{ Overbank sediment } & \\
\hline & & $0-59 \mathrm{~cm}^{\mathrm{a}}$ & $59-114 \mathrm{~cm}^{\mathrm{a}}$ & $114-183 \mathrm{~cm}^{\mathrm{a}}$ & $183-206 \mathrm{~cm}^{\mathrm{a}}$ & $206-225 \mathrm{~cm}^{\mathrm{a}}$ & \\
\hline \multirow{3}{*}{$\begin{array}{l}\text { Samples analysed } \\
\text { using EXAFS }\end{array}$} & LC04 & PB21 & PB12 & PB05 & PB02 & PB01 & GE10 \\
\hline & LC07 & PB30 & PB17 & PB08 & PB03 & & \\
\hline & LC09 & PB32 & PB20 & PB11 & & & \\
\hline \multirow[t]{2}{*}{ Description } & $\begin{array}{c}\text { Loam, (sandy } \\
\text { loam) }^{\mathrm{b}}\end{array}$ & Sandy loam & Loam & Loam & Loam & Sandy clay & Coarse sand \\
\hline & $\begin{array}{c}\text { Brown, (brownish } \\
\text { black) }^{\mathrm{b}}\end{array}$ & Dark brown & Brown & Brown & Brown & Gray & $\begin{array}{l}\text { Brownish } \\
\text { black }\end{array}$ \\
\hline $\mathrm{Zn}(\mathrm{mg} / \mathrm{kg})$ & $10000-69000$ & $4000-12000$ & $5200-12000$ & $7800-12000$ & $5200-6600$ & 7600 & 3200 \\
\hline $\mathrm{Pb}(\mathrm{mg} / \mathrm{kg})$ & $410-2200$ & $2100-5400$ & $530-3000$ & $330-430$ & $400-1200$ & 1800 & 600 \\
\hline $\mathrm{Cd}(\mathrm{mg} / \mathrm{kg})$ & $6-18$ & $9-29$ & $7-23$ & $4-12$ & $4-5$ & 6 & 5 \\
\hline As $(\mathrm{mg} / \mathrm{kg})$ & $11-38$ & $32-89$ & $12-18$ & $12-13$ & $13-19$ & 5 & 25 \\
\hline $\mathrm{Cu}(\mathrm{mg} / \mathrm{kg})$ & $15-24$ & $32-73$ & $14-28$ & $12-13$ & $12-18$ & 14 & 19 \\
\hline $\operatorname{Mn}(\mathrm{mg} / \mathrm{kg})$ & $440-2300$ & $350-570$ & $400-450$ & $380-510$ & $210-640$ & 66 & 340 \\
\hline $\mathrm{Fe}(\%)$ & $1.7-3.5$ & $1.7-2.9$ & $1.6-1.9$ & $1.7-1.9$ & $1.9-2.7$ & 1.1 & 1.5 \\
\hline $\mathrm{Ca}(\%)$ & $0.67-1.1$ & $0.31-0.50$ & $0.26-0.55$ & $0.25-0.35$ & $0.23-0.32$ & 0.32 & 0.70 \\
\hline $\operatorname{Mg}(\%)$ & $0.29-0.56$ & $0.10-0.13$ & $0.08-0.14$ & $0.08-0.12$ & $0.08-0.12$ & 0.11 & 0.20 \\
\hline $\mathrm{K}(\%)$ & $0.85-1.3$ & $0.84-1.2$ & $1.1-1.3$ & $1.0-1.4$ & $1.1-1.3$ & 1.2 & 0.72 \\
\hline $\mathrm{Al}(\%)$ & $3.7-4.7$ & $1.1-3.9$ & $2.1-2.6$ & $2.2-2.8$ & $1.9-3.2$ & 3.1 & nd \\
\hline $\mathrm{S}(\%)$ & $<0.1$ & $<0.1-0.2$ & $<0.1$ & $<0.1$ & $<0.1$ & $<0.1$ & nd \\
\hline Org C (\%) & $0.6-4.4$ & $2.0-3.8$ & $1.1-2.2$ & $0.9-1.1$ & $0.9-2.7$ & 0.4 & 1.3 \\
\hline $\mathrm{pH}$ (water) & $7.2-7.8$ & $6.7-7.6$ & $6.9-7.6$ & $7.7-8.0$ & $7.2-7.4$ & 7.6 & 7.7 \\
\hline $\mathrm{pH}\left(\mathrm{CaCl}_{2}\right)$ & nd & $6.1-6.8$ & $6.4-7.1$ & $7.2-7.4$ & $6.7-6.8$ & 7.4 & nd \\
\hline Clay $(\text { vol\%) })^{\mathrm{c}}$ & nd & $20-25$ & $18-22$ & $19-21$ & $18-22$ & 42 & 16 \\
\hline Silt (vol\%) & nd & $30-40$ & $33-38$ & $37-40$ & $29-31$ & 32 & 17 \\
\hline Sand (vol\%) & nd & $38-48$ & $40-47$ & $38-43$ & $49-52$ & 26 & 67 \\
\hline Zn-minerals ${ }^{d}$ & $\begin{array}{c}\text { smithsonite } \\
\text { hemimorphite }\end{array}$ & $\begin{array}{c}\text { smithsonite } \\
\text { hemimorphite } \\
\text { willemite }\end{array}$ & nd & smithsonite & nd & nd & $\begin{array}{c}\text { smithsonite } \\
\text { hemimorphite } \\
\text { willemite } \\
\text { sphalerite }\end{array}$ \\
\hline
\end{tabular}

nd: not determined. ${ }^{\text {a }}$ The PB samples were grouped in depth intervals using boundaries of sedimentary units and noteworthy differences in $\mathrm{Zn}$ or $\mathrm{Pb}$ concentration (Fig. 6a).

${ }^{b}$ Descriptions between brackets only apply to the upper $20 \mathrm{~cm}$ interval. ${ }^{\mathrm{c}} 0-8 \mu \mathrm{m}$ fraction, taking into account the underestimation of the clay content by laser diffractometry (Konert and Vandenberghe, 1997). ${ }^{\mathrm{d}}$ Identified using XRD on bulk samples and/or concentrates, separated by sieving $(125-250 \mu \mathrm{m})$, density $(d>2.9 \mathrm{~g} / \mathrm{mL})$ and magnetic fractionation. 
Table 2: Results of the principal component analysis of the twenty-two EXAFS spectra.

\begin{tabular}{cccc}
\hline $\mathrm{C}^{\mathrm{a}}$ & Eigenvalue & $\mathrm{IND}^{\mathrm{b}}$ & $\begin{array}{c}\mathrm{NSS}_{\mathrm{tot}}{ }^{\mathrm{c}} \\
\left(\times 10^{2}\right)\end{array}$ \\
\hline 1 & 169 & 0.0209 & 5.87 \\
2 & 34.6 & 0.0135 & 1.92 \\
3 & 16.9 & 0.0109 & 0.971 \\
4 & 8.09 & 0.0110 & 0.755 \\
5 & 6.18 & 0.0116 & 0.628 \\
6 & 5.47 & 0.0124 & 0.529 \\
7 & 5.18 & 0.0133 & 0.441 \\
8 & 4.58 & 0.0145 & 0.372 \\
\hline
\end{tabular}

${ }^{\mathrm{a}}$ Component. ${ }^{\mathrm{b}}$ Indicator value (Malinowski, 1977, 1978).

${ }^{\mathrm{c}} \mathrm{NSS}_{\mathrm{tot}}=\Sigma_{\text {spectra }} \Sigma_{\mathrm{i}}\left[k^{3} \chi\left(k_{i}\right)_{\mathrm{exp}}-k^{3} \chi\left(k_{i}\right)_{\text {reconstr }}\right]^{2} / \Sigma_{\text {spectra }} \Sigma_{\mathrm{i}}\left[k^{3} \chi\left(k_{i}\right)_{\mathrm{exp}}\right]^{2}$ 
Table 3: Proportions of $\mathrm{Zn}$ species determined by linear combination fitting.

\begin{tabular}{|c|c|c|c|c|c|c|c|c|}
\hline Sample & $\begin{array}{l}\text { P.s. fr. } \\
(\mathrm{mm})\end{array}$ & $\begin{array}{l}\text { Depth } \\
(\mathrm{cm})\end{array}$ & $\begin{array}{l}\text { Total Zn } \\
(\mathrm{mg} / \mathrm{kg})\end{array}$ & $\begin{array}{l}\mathrm{Sm}^{\mathrm{b}} \\
(\%)\end{array}$ & $\begin{array}{c}\text { ZnKer240 } \\
(\%)\end{array}$ & $\begin{array}{c}{ }^{\mathrm{IV}} \mathrm{Zn}^{\mathrm{d}} \\
(\%)\end{array}$ & $\begin{array}{l}\text { Sum } \\
(\%)\end{array}$ & $\begin{array}{l}\mathrm{NSS}^{\mathrm{e}} \\
\left(\times 10^{2}\right)\end{array}$ \\
\hline PB01 & $0-2$ & $206-225$ & 7600 & 19 & 72 & 10 & 101 & 3.38 \\
\hline PB02 & $0-2$ & $203-206$ & 6600 & - & 107 & - & 107 & 3.32 \\
\hline PB03 & $0-2$ & 193-203 & 5700 & - & 108 & - & 108 & 3.02 \\
\hline PB05 & $0-2$ & $173-183$ & 7800 & 22 & 83 & - & 105 & 2.76 \\
\hline \multirow[t]{2}{*}{ PB08 } & $0-2$ & $147-155$ & 10300 & 22 & 82 & - & 104 & 1.61 \\
\hline & $0-0.002$ & $147-155$ & nd & - & 113 & - & 113 & 1.87 \\
\hline PB11 & $0-2$ & $114-125$ & 9800 & 29 & 66 & 8 & 103 & 1.95 \\
\hline PB12 & $0-2$ & $107-114$ & 8300 & 28 & 69 & 13 & 110 & 4.35 \\
\hline PB17 & $0-2$ & $75-81$ & 5200 & 7 & 73 & 26 & 106 & 3.09 \\
\hline PB20 & $0-2$ & $59-64$ & 12000 & - & 71 & 24 & 95 & 2.65 \\
\hline \multirow[t]{4}{*}{ PB21 } & $0-2$ & $55-59$ & 12200 & - & 63 & 28 & 91 & 3.12 \\
\hline & $1-2$ & $55-59$ & 16400 & 6 & 72 & 27 & 105 & 1.34 \\
\hline & $0.125-0.250$ & $55-59$ & 11200 & - & 66 & 25 & 91 & 3.26 \\
\hline & $0-0.002$ & $55-59$ & nd & - & 100 & 11 & 111 & 1.39 \\
\hline \multirow[t]{2}{*}{ PB30 } & $0-2$ & $13-19$ & 7100 & 7 & 56 & 30 & 93 & 3.73 \\
\hline & $0-0.002$ & $13-19$ & nd & - & 86 & 20 & 106 & 1.53 \\
\hline PB32 & $0-2$ & $0-7$ & 4000 & - & 67 & 30 & 97 & 3.18 \\
\hline \multirow[t]{2}{*}{ LC04 } & $0-2$ & $168-183$ & 69000 & 55 & 47 & - & 102 & 0.816 \\
\hline & $0-0.002$ & $168-183$ & nd & - & 117 & - & 117 & 1.58 \\
\hline LC07 & $0-2$ & $123-138$ & 29000 & 58 & 50 & - & 108 & 0.881 \\
\hline LC09 & $0-2$ & $93-108$ & 47000 & 60 & 38 & 12 & 110 & 0.899 \\
\hline GE10 & $0-2$ & - & 3200 & 21 & 63 & $24^{\mathrm{f}}$ & 108 & 4.20 \\
\hline
\end{tabular}

nd: not determined. ${ }^{a}$ Particle size fraction. ${ }^{b}$ Smithsonite $\left(\mathrm{ZnCO}_{3}\right) .{ }^{\mathrm{c}} \mathrm{Zn}$-rich kerolite $\left(\mathrm{Si}_{4}\left(\mathrm{Zn}_{2.4} \mathrm{Mg}_{0.6}\right) \mathrm{O}_{10}(\mathrm{OH})_{2} \cdot \mathrm{nH}_{2} \mathrm{O}\right) .{ }^{\mathrm{d}}$ Tetrahedrally coordinated sorbed $\mathrm{Zn}$, with $\mathrm{ZnFh}$ as proxy. ${ }^{\mathrm{e}} \mathrm{NSS}=\Sigma_{\mathrm{i}}\left[k^{3} \chi\left(k_{i}\right)_{\mathrm{exp}}-k^{3} \chi\left(k_{i}\right)_{\text {reconstr }}\right]^{2} / \Sigma_{\mathrm{i}}\left[k^{3} \chi\left(k_{i}\right)_{\exp }\right]^{2}$. ${ }^{\mathrm{f}}$ Refers to hemimorphite, not ${ }^{\mathrm{IV}} \mathrm{Zn}$. Smithsonite and sorbed ${ }^{\mathrm{IV}} \mathrm{Zn}$ fractions between 5 and $10 \%$ may not be significant. 


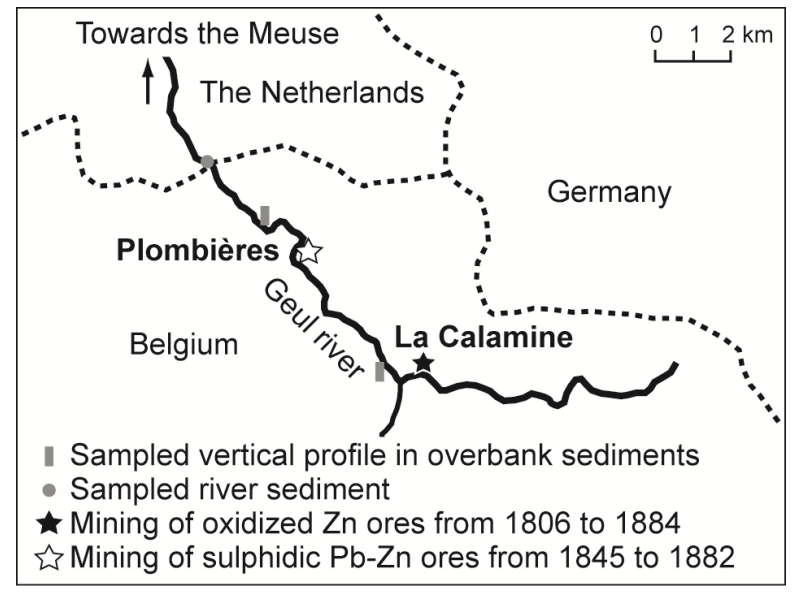

Fig. 1. Geographical setting of the Geul river, sampling sites and major mines. Mining already took place in the Middle Ages, and reached its apogee during the 19th century. Smelters were located nearby the mines. 


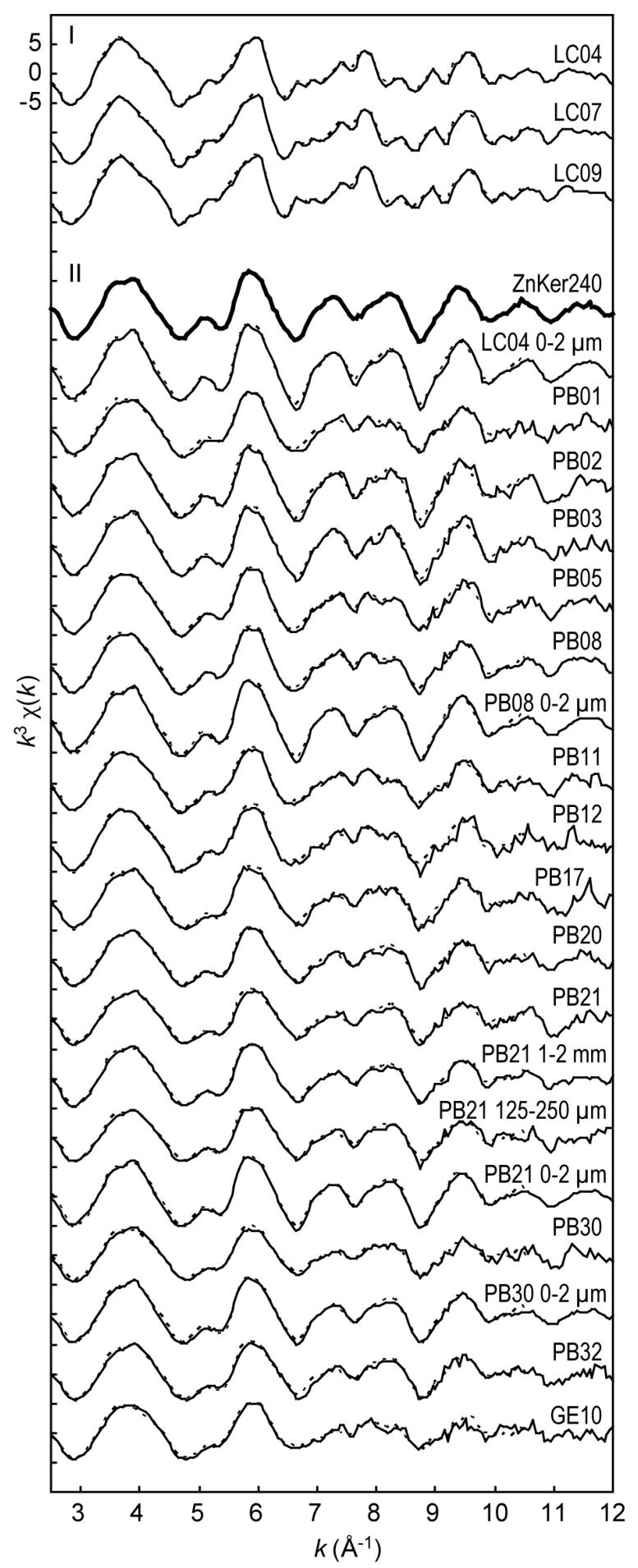

Fig. 2. 
Fig. 2. Powder Zn K-edge $k^{3}$-weighted EXAFS spectra (full lines) and LCF simulations (dashed lines). The proportions of $\mathrm{Zn}$ species are reported in Table 3. The particle size fraction is 0-2 mm, unless stated otherwise. Spectra are classified into two groups according to their shape in the $k$-interval $\sim 7-8.5 \AA^{-1}$. The spectra of the second group show similarities with $\mathrm{Zn}$-containing kerolite $\left(\mathrm{Si}_{4}\left(\mathrm{Zn}_{2.4} \mathrm{Mg}_{0.6}\right) \mathrm{O}_{10}(\mathrm{OH})_{2} \cdot \mathrm{nH}_{2} \mathrm{O}, \mathrm{ZnKer} 240\right)$. 


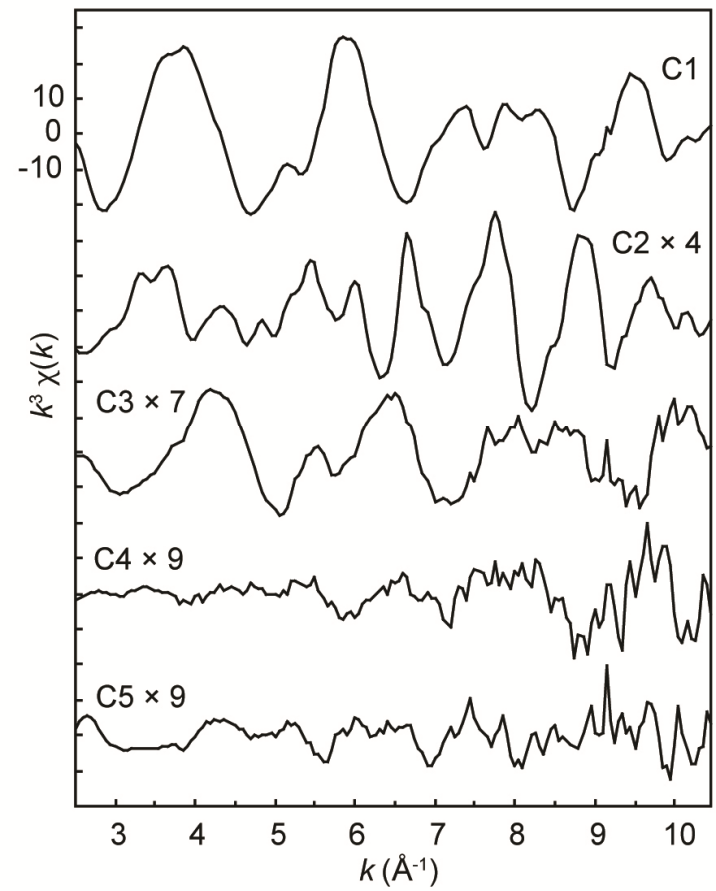

Fig. 3. First five principal components (C1-C5) weighted by eigenvalues for the twentytwo $k^{3} \chi(k)$ spectra shown in Fig. 2. For clarity, the amplitudes of C2, C3, C4 and C5 were multiplied by 4, 7, 9 and 9 , respectively. 


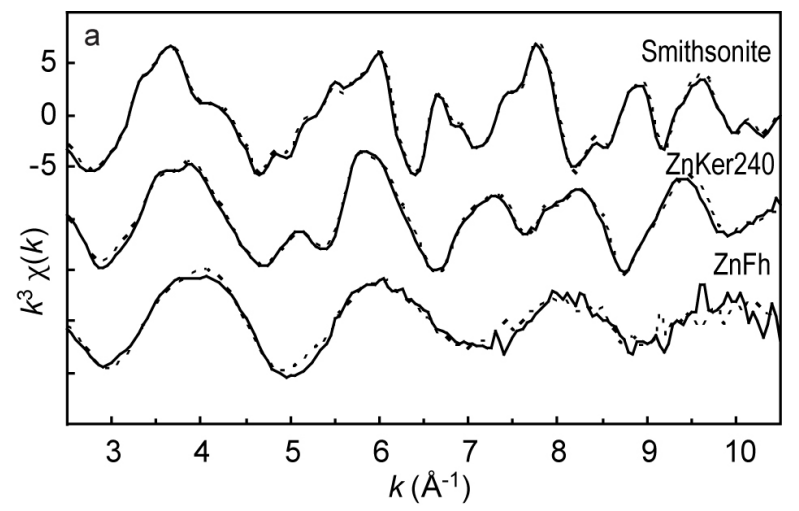

Fig. 4a.

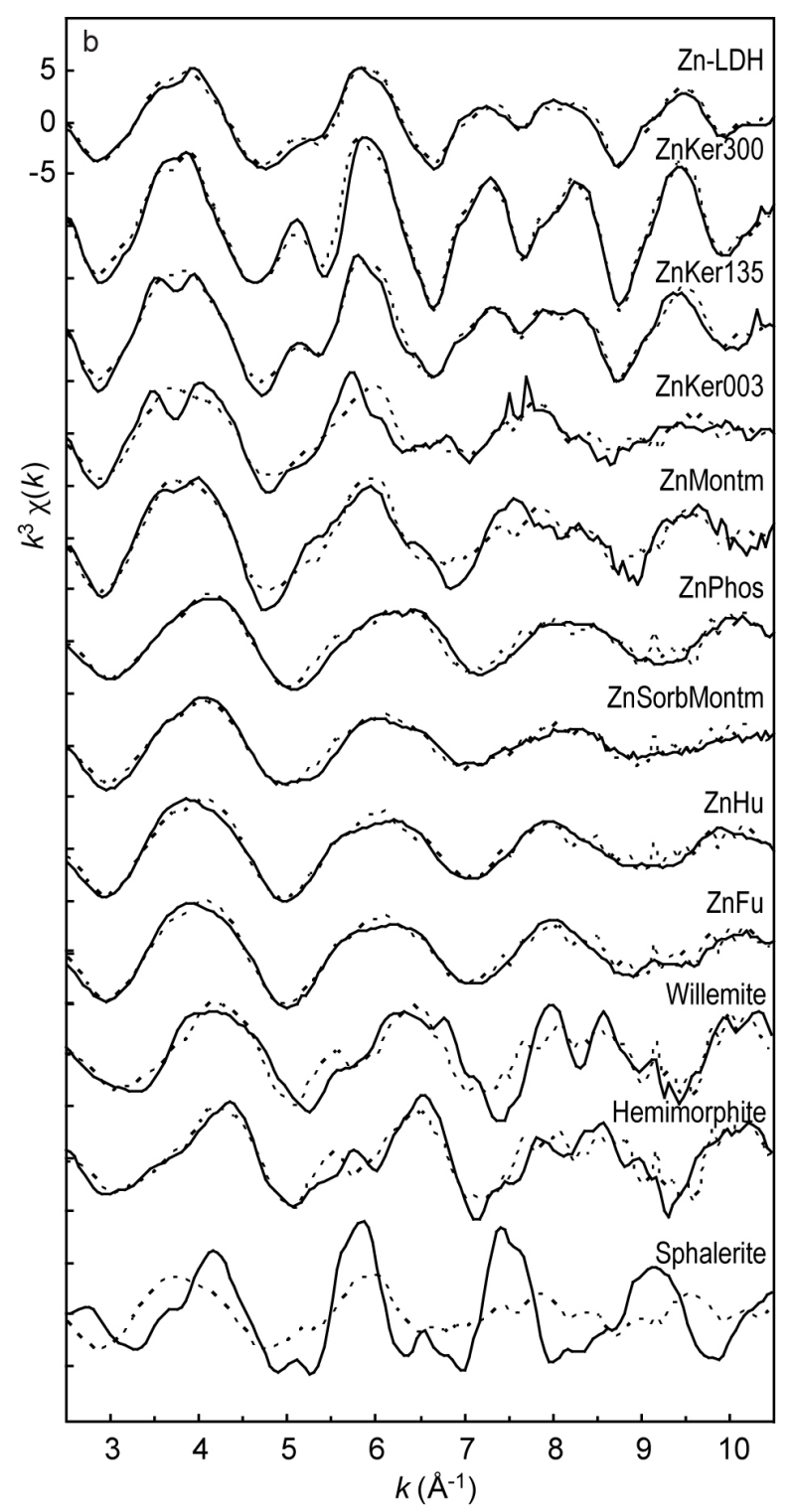

Fig. 4b. 
Fig. 4. Zn K-edge EXAFS spectra (full lines) and target transformations (dashed lines) of $\mathrm{Zn}$ reference compounds. (a) Successful target transformations: smithsonite $\left(\mathrm{ZnCO}_{3}\right), \mathrm{Zn}$ rich kerolite $\left(\mathrm{Si}_{4}\left(\mathrm{Zn}_{2.4} \mathrm{Mg}_{0.6}\right) \mathrm{O}_{10}(\mathrm{OH})_{2} \cdot \mathrm{nH}_{2} \mathrm{O}, \mathrm{ZnKer} 240\right)$, $\mathrm{Zn}$-sorbed ferrihydrite $(\mathrm{ZnFh})$; (b) Less or unsuccessful target transformations (selection): Zn layered double hydroxide $\left(\mathrm{Zn}_{2} \mathrm{Al}(\mathrm{OH})_{6} \mathrm{Cl}, \mathrm{Zn}-\mathrm{LDH}\right)$, low $\mathrm{Zn}$-containing kerolite $\left(\mathrm{Si}_{4}\left(\mathrm{Zn}_{0.03} \mathrm{Mg}_{2.97}\right) \mathrm{O}_{10}(\mathrm{OH})_{2} \cdot \mathrm{nH}_{2} \mathrm{O}\right.$, ZnKer003), medium Zn-containing kerolite $\left(\mathrm{Si}_{4}\left(\mathrm{Zn}_{1.35} \mathrm{Mg}_{1.65}\right) \mathrm{O}_{10}(\mathrm{OH})_{2} \cdot \mathrm{nH}_{2} \mathrm{O}, \mathrm{ZnKer} 135\right)$, pure $\mathrm{Zn}$-kerolite $\left(\mathrm{Si}_{4} \mathrm{Zn}_{3} \mathrm{O}_{10}(\mathrm{OH})_{2} \cdot \mathrm{nH}_{2} \mathrm{O}, \mathrm{ZnKer} 300\right)$, Zn-substituted montmorillonite (ZnMontm), Zn-reacted hydroxylapatite $\left(\mathrm{Ca}_{10}\left(\mathrm{PO}_{4}\right)_{6}(\mathrm{OH})_{2}\right)$ (ZnPhos), Zn-sorbed montmorillonite (ZnSorbMontm), Zn-humic acid (ZnHu), Zn-fulvic acid (ZnFu), willemite $\left(\mathrm{Zn}_{2} \mathrm{SiO}_{4}\right)$, hemimorphite $\left(\mathrm{Zn}_{4} \mathrm{Si}_{2} \mathrm{O}_{7}(\mathrm{OH})_{2} \cdot \mathrm{H}_{2} \mathrm{O}\right)$ and sphalerite $(\mathrm{ZnS})$. 


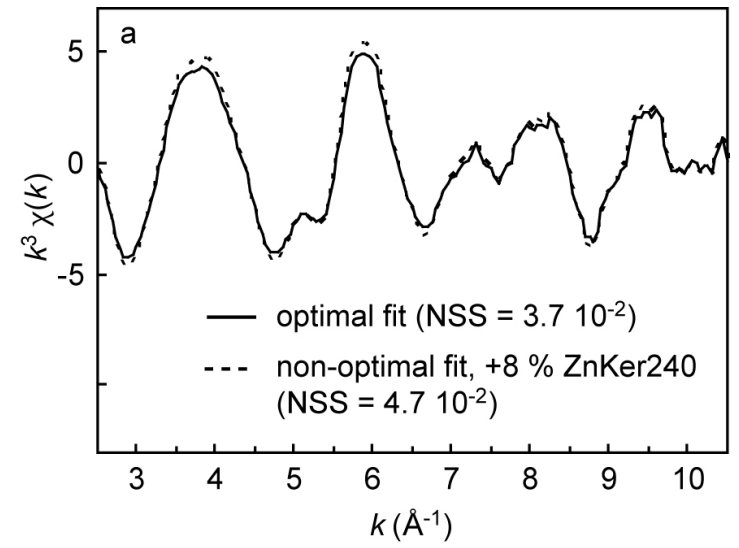

Fig. 5a.

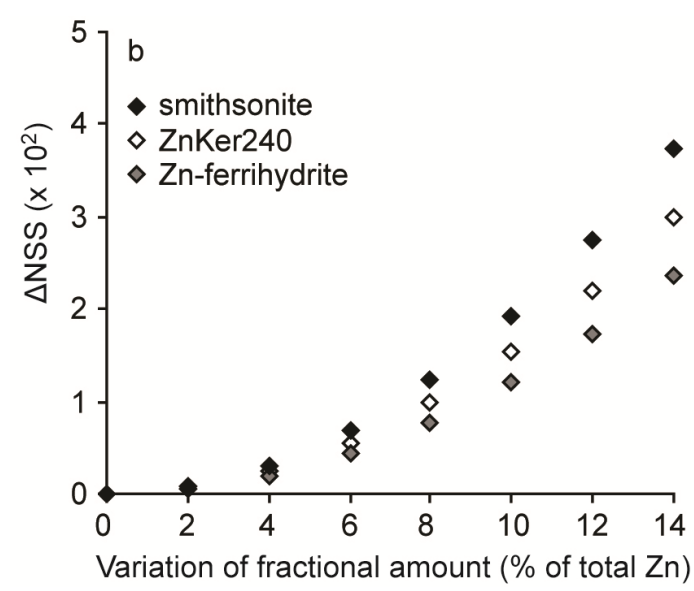

Fig. 5b.

Fig. 5. Evaluation of the precision on the proportion of smithsonite, ZnKer240 and ZnFh determined by LCF, illustrated with the bulk spectrum PB30. The NSS value was calculated for successive linear combinations, each deviating from the optimal fit in the proportion of one species at a time. (a) An increase in the NSS of 0.01 , obtained here by increasing the optimal proportion of ZnKer240 by $8 \%$ of total $\mathrm{Zn}$, clearly degraded the fit. Therefore, the value of 0.01 was retained to estimate the precision on the proportion of each species. (b) The deviation of NSS ( $\triangle$ NSS; Y-axis) from its optimal value (Table 3 ) upon variation of the fractional amount of one species (X-axis). 

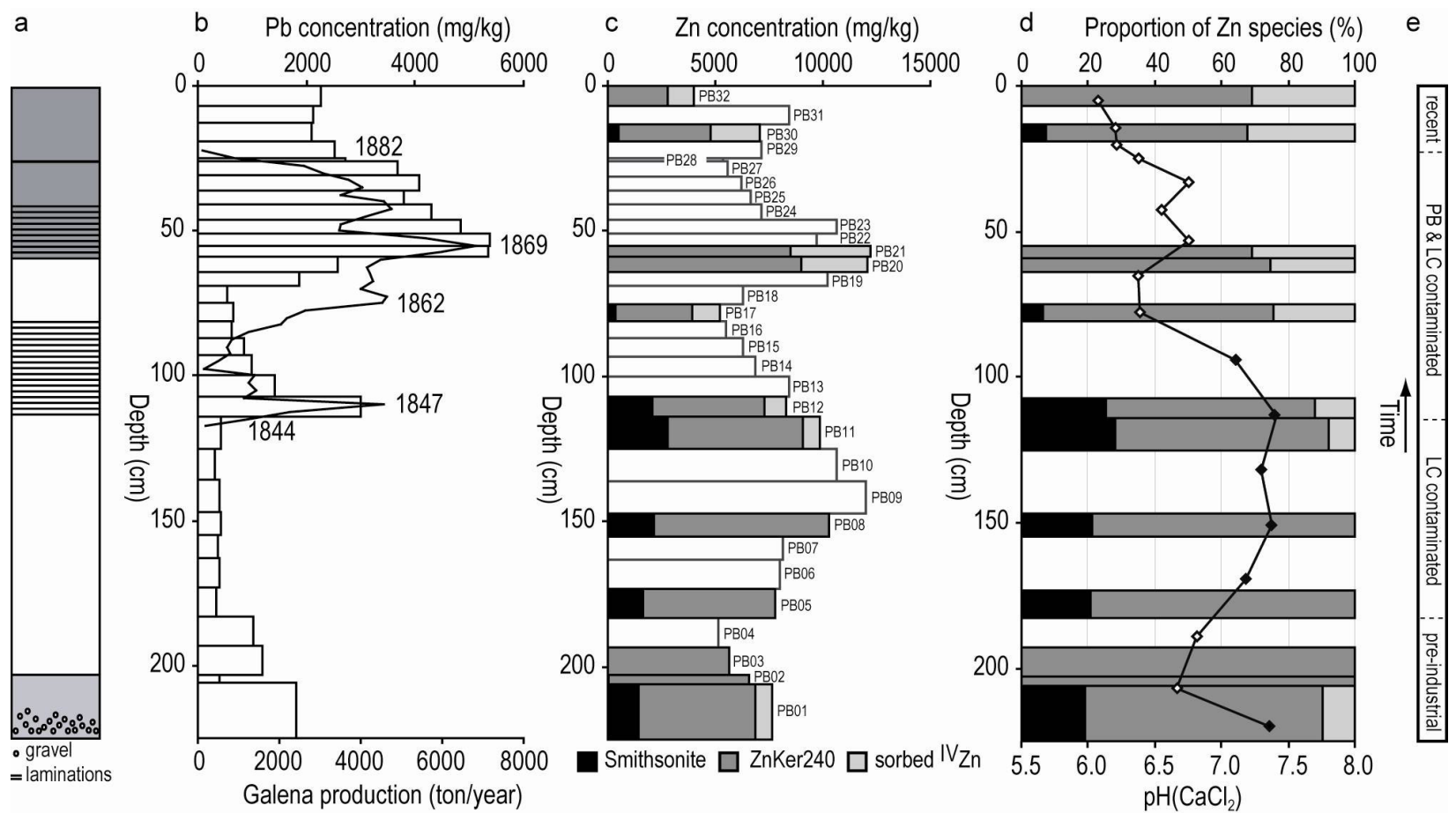

Fig. 6. Vertical profile in overbank sediments near Plombières. (a) Schematic overview (sediment colors are given in Table 1). (b) Concentrations of $\mathrm{Pb}$ (bars), and galena production of the Plombières mine (full line; Dejonghe et al., 1993). The two patterns could be matched by assuming a constant sedimentation rate of $2.5 \mathrm{~cm} /$ year, allowing approximative dating of the sediment column. (c) Concentrations of $\mathrm{Zn}$ (bars) and results from the LCF analysis in absolute values (normalized fraction multiplied by total $\mathrm{Zn}$ concentration). (d) Results from the LCF analysis as percentage of total $\mathrm{Zn}$ (bars; the sum of $\mathrm{Zn}$ species was normalized to $100 \%$ to facilitate comparison between samples), and $\mathrm{pH}\left(\mathrm{CaCl}_{2}\right)$ (open and closed symbols as in Fig. 7). (e) Estimated relationship between sediment depth and contamination history: 'pre-industrial' - deposition before the start of industrial operations; 'LC contaminated' - contamination mainly with oxidized Zn minerals from the La Calamine mine; 'PB \& LC contaminated' - co-contamination with $\mathrm{Pb}-\mathrm{Zn}$ sulphides from Plombières in addition to oxidized $\mathrm{Zn}$ ores; 'recent'- deposition after the cessation of most industrial activities. 


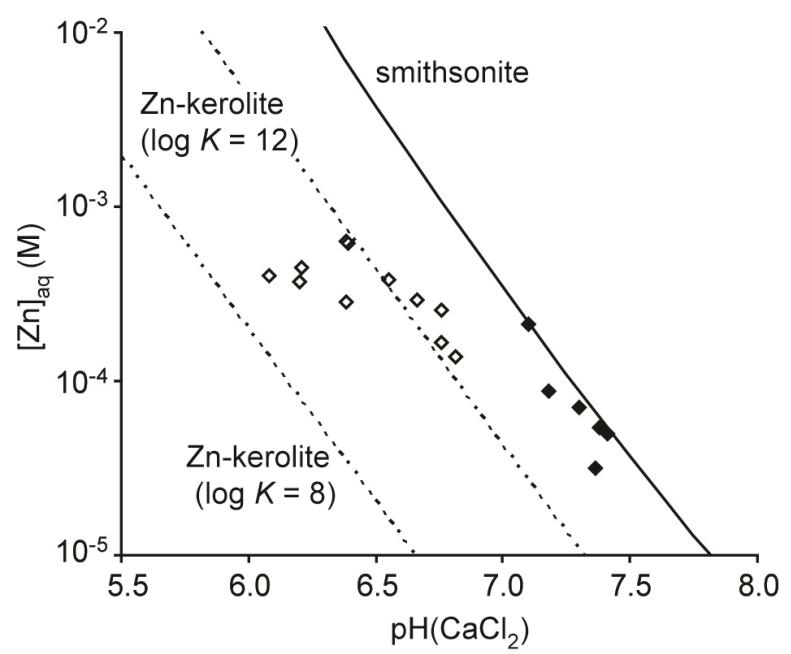

Fig. 7. Zinc concentrations in $10^{-2} \mathrm{M} \mathrm{CaCl}_{2}$ extracts of the PB samples (symbols) and predicted values at equilibrium with smithsonite $(\log K=10.9)$ and with Zn-kerolite (log $K=8$ and 12) (lines) at $\mathrm{CO}_{2}$ partial pressure of $10^{-3}$ atm, and $\mathrm{Si}$ and $\mathrm{CaCl}_{2}$ concentrations of $10^{-4} \mathrm{M}$ and $10^{-2} \mathrm{M}$, respectively. At $\mathrm{pH}\left(\mathrm{CaCl}_{2}\right)>7.0$ (closed symbols), the aqueous $\mathrm{Zn}$ concentration seems to be controlled by smithsonite dissolution, whereas at $\mathrm{pH}\left(\mathrm{CaCl}_{2}\right)<$ 7.0 (open symbols), aqueous $\mathrm{Zn}$ is potentially controlled by $\mathrm{Zn}$-kerolite or sorbed $\mathrm{Zn}$.

Solubility data are consistent with EXAFS results, because smithsonite amounts to $>20 \%$ of $\mathrm{Zn}$ in samples with $\mathrm{pH}>7.0$, and $<10 \%$ in samples with $\mathrm{pH}<7.0$ (Fig. 6d). 


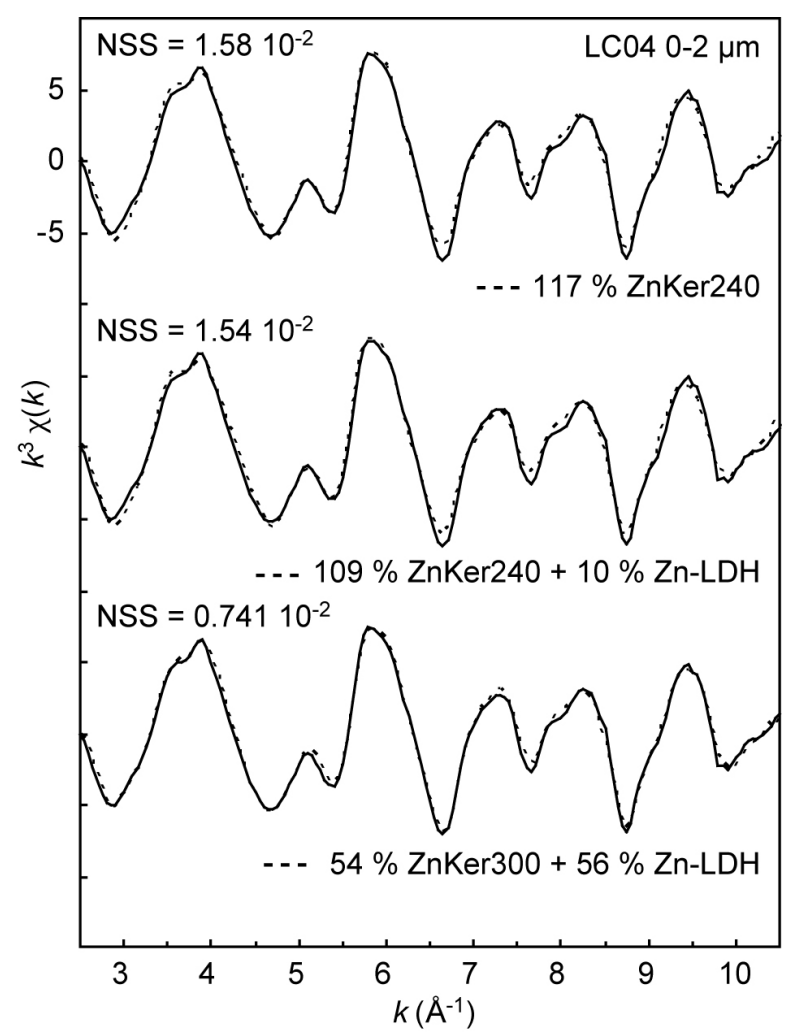

Fig. 8. Zn K-edge EXAFS spectrum of the 0-2 $\mu \mathrm{m}$ fraction for LC04 (full lines) with fits using different combinations of ZnKer240, ZnKer300 and Zn-LDH (dashed lines).

Although the best fit was obtained with a one-to-one mixture of ZnKer300 and Zn-LDH, differences are minor and this mathematical solution probably is mineralogically incorrect (see main text for discussion). 